\title{
What does a linguistic expert know? The conflict between analogy and Atticism
}

Book or Report Section

Published Version

Dickey, E. ORCID: https://orcid.org/0000-0002-4272-4803 (2019) What does a linguistic expert know? The conflict between analogy and Atticism. In: Adams, S. A. (ed.) Scholastic Culture in the Hellenistic and Roman Eras. De Gruyter, Berlin, pp. 103-118. ISBN 9783110657876 doi: https://doi.org/10.1515/9783110660982-008 Available at http://centaur.reading.ac.uk/95243/

It is advisable to refer to the publisher's version if you intend to cite from the work. See Guidance on citing.

To link to this article DOI: http://dx.doi.org/10.1515/9783110660982-008

Publisher: De Gruyter

All outputs in CentAUR are protected by Intellectual Property Rights law, including copyright law. Copyright and IPR is retained by the creators or other copyright holders. Terms and conditions for use of this material are defined in the End User Agreement. 


\section{www.reading.ac.uk/centaur}

\section{CentAUR}

Central Archive at the University of Reading

Reading's research outputs online 


\section{Scholastic Culture in the Hellenistic and Roman Eras}

Greek, Latin, and Jewish

Edited by Sean A. Adams 
ISBN 978-3-11-065787-6

e-ISBN (PDF) 978-3-11-066098-2

e-ISBN (EPUB) 978-3-11-065799-9

ISSN 2625-4018

\section{Library of Congress Control Number: 2019947085}

\section{Bibliographic information published by the Deutsche Nationalbibliothek}

The Deutsche Nationalbibliothek lists this publication in the Deutsche Nationalbibliografie; detailed bibliographic data are available on the Internet at http://dnb.dnb.de.

(C) 2019 Walter de Gruyter GmbH, Berlin/Boston

Cover image: Salone Sansovino @ Biblioteca Nazionale Marciana

Printing \& binding: CPI books GmbH, Leck

www.degruyter.com 


\section{Contents}

Sean A. Adams

Introduction: Themes in Ancient Scholarship - 1

Gaëlle Coqueugniot

Scholastic Research in the Archive? Hellenistic Historians and Ancient Archival Records - 7

Myrto Hatzimichali

Circulation of Lexica in the Hellenistic and Early Imperial Period - 31

Matthew Nicholls

'Bookish Places' in Imperial Rome: Bookshops and the Urban Landscape of Learning - 51

Serena Ammirati

Towards a Typology of the Ancient Latin Legal Book - 69

Stephanie Roussou

New Readings in the Text of Herodian -83

Eleanor Dickey

What does a Linguistic Expert Know? The Conflict between Analogy and Atticism - 103

R.M.A. Marshall

Suetonius the Bibliographer — 119

Sean A. Adams

Translating Texts: Contrasting Roman and Jewish Depictions of Literary

Translations - 147

Catherine Hezser

Rabbis as Intellectuals in the Context of Graeco-Roman and Byzantine Christian Scholasticism — 169

Bibliography - 187

Subject Index — 211

Author Index - 213

Works Cited -219 
Eleanor Dickey

\section{What does a Linguistic Expert Know? The Conflict between Analogy and Atticism}

The phrase 'linguistic expert' ought to be an oxymoron. Language consists of a set of arbitrary conventions shared by members of a given community: it is simply whatever the members of that community do when they open their mouths, and therefore no member of the community should be able to have any special status in relation to it. Yet expertise is precisely a special status, one that arises from a community's belief that an individual has worthwhile knowledge not shared by most other people: an expert is not simply someone who knows something unusual, but someone whose unusual knowledge is recognised by others. How does a community decide that some people know more than others about something that consists only of what everyone does?

There are, of course, many answers to this question, for there are many different possible bases on which linguistic expertise can be claimed, depending on the community involved. Some cultures do not have the concept of linguistic expertise or linguistic correctness at all, and these cultures are not necessarily primitive or unsophisticated: it has been persuasively argued that Aeschylus's Athens was one of them. ${ }^{1}$ Yet later Greek speakers clearly did have linguistic experts, and moreover the basis of their expert status seems to have changed over time. How did this situation arise?

\section{Linguistic expertise based on knowledge of analogical rules}

The earliest substantial evidence for the existence of linguistic experts in Greece can be seen in passage 1, from Aristophanes' Clouds, in which Socrates is presented as such an expert:

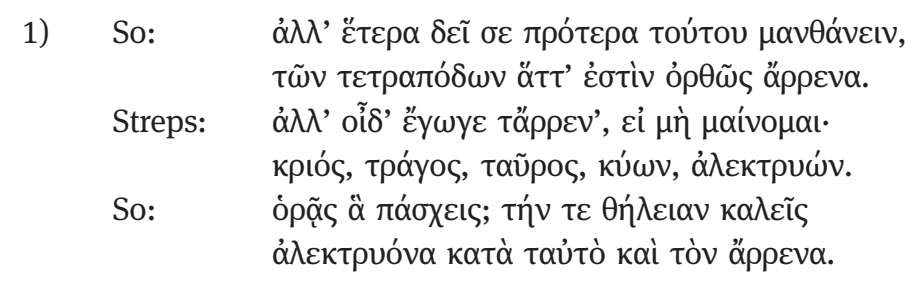

1 West (1990) $10-12$.

Eleanor Dickey, University of Reading

https://doi.org/10.1515/9783110660982-008 


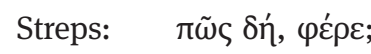

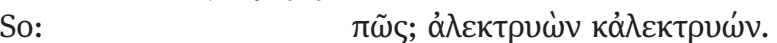

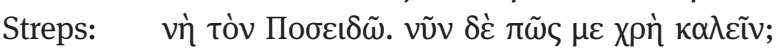

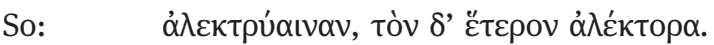

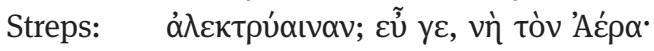

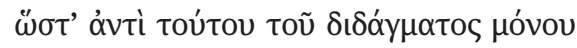

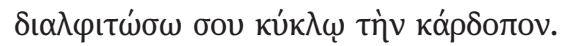

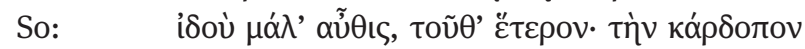

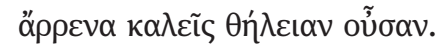

Streps:

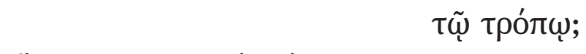

So:

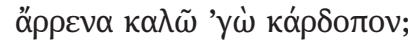

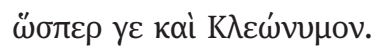
$\mu \alpha \dot{\lambda}\lrcorner \sigma \tau \alpha \dot{~} \gamma \varepsilon$,

Streps:

So:

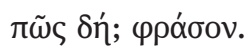

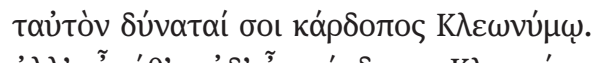

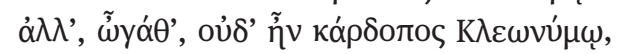

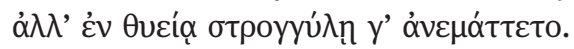

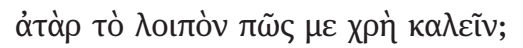

So:

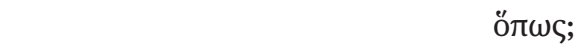

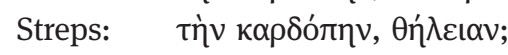

So:

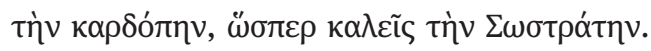

Streps:

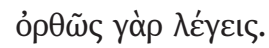

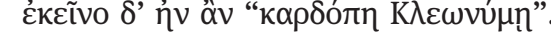

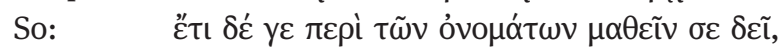

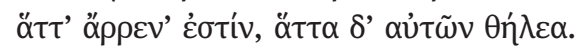

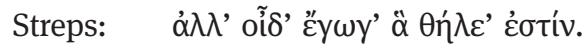

So:

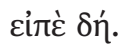

Streps:

So:

Streps: $\Lambda$

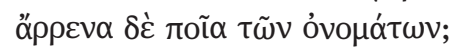

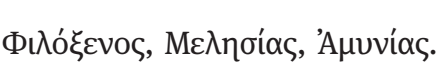
$\mu$ pía.

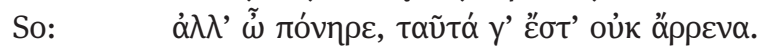

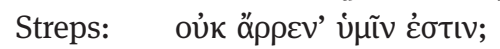

So:

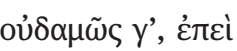

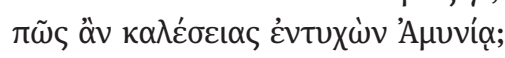

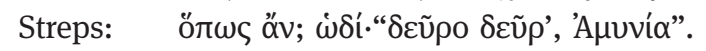

So: $\quad$ ópạ̃

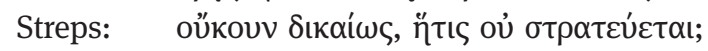

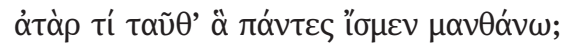

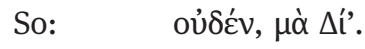

So: $\quad$ But there are other things you must learn before that, such as which of the quadrupeds are properly called masculine.

Streps: Well, I know which are masculine, if I've not lost my wits: ram, he-goat, bull, dog, fowl.

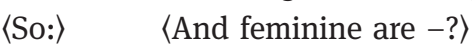

〈Streps:〉 〈Ewe, she-goat, cow, bitch, fowl.〉

So: $\quad$ Do you see what you're doing? You call the female 'fowl', and the male as well you call the same thing. 


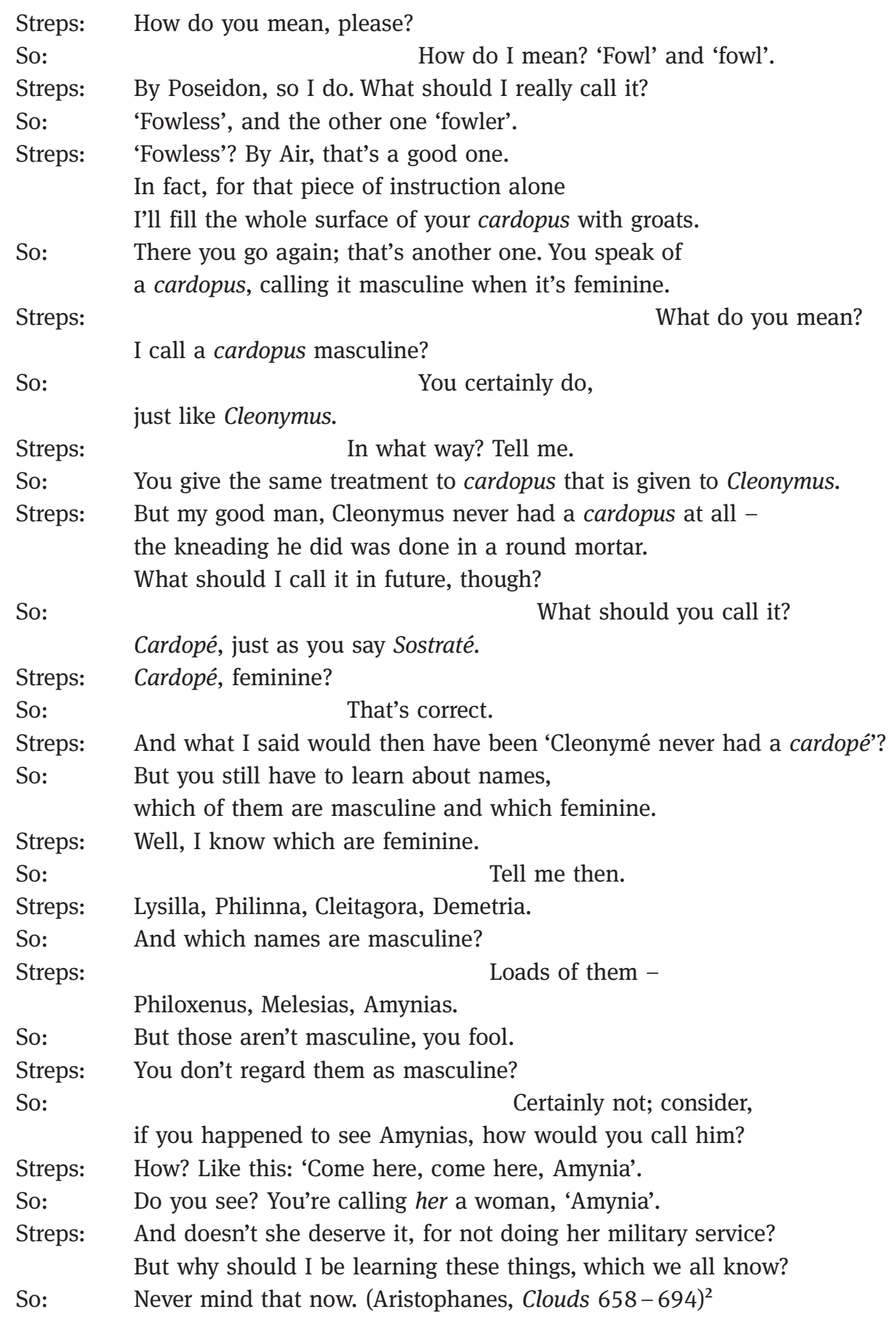

Here the expertise is based on observation of regularities in language and the construction of rules based on those regularities; those rules are in turn used to produce arguments that what ordinary people do is wrong, arguments that win praise and admiration. There must be some resemblance between this passage and debates actually occurring in fifth-century Athens, as otherwise the parody would not have been funny. At a minimum this resemblance probably includes the expert's success in con-

2 Translation from Sommerstein (1991) 71-75. 
vincing others of the validity and value of his linguistic knowledge (although part of the joke here may be on Strepsiades for being so easily impressed, the whole set of arguments would not have been worth parodying if they had not been gaining any traction at all in real life) as well as the basis of the expertise itself: the construction of rules based on observed regularities in language.

At the same time the parody is unlikely to be accurate in every detail, and indeed one major inaccuracy is apparent: nothing else we know about Socrates suggests that he was a linguistic expert. Indeed, a claim of expert status in any area would be a major contradiction to Plato's portrayal of Socrates as someone who presented himself as knowing nothing. While allowing that Plato's portrayal is also unlikely to be completely accurate, most scholars think that the subject of this parody is probably not Socrates at all. The Clouds mocks sophists in general and uses the name 'Socrates' for a composite character made up of features of different individuals, and here the sophists being parodied are likely to be Prodicus and/or Protagoras. ${ }^{3}$

The basis of expertise portrayed in this passage is part of a larger pattern of how early Greek philosophy worked: the philosophers discovered previously unnoticed regular patterns in mathematics, astronomy, and other aspects of the natural world, and in many cases they were able to use those patterns to gain real information that non-experts did not have. Given the largely regular nature of language, it would have been surprising if early Greek philosophers had not noticed the regular patterns of Greek and played around with the irregularities.

Another, much later, parody suggests the same basis for linguistic expertise. This comes from the Roman-period Sceptic philosopher Sextus Empiricus, who was opposed on principle to experts of any sort: Sextus systematically attacked people who claimed to be experts, on the grounds that they were fakes. Significantly, linguistic expertise gets pride of place in his attacks, with 'Against the Grammarians' being the first book of a systematic demolition of experts (other targets are specialists in rhetoric, geometry, arithmetic, astrology, music, logic, physics, and ethics). This prominent position shows that in Sextus' day there must have been a body of linguistic experts large enough, and influential enough, to make good targets - and they must have used arguments broadly similar to the ones he tries to refute. The crucial elements of his argument can be seen in passage 2 .

3 See e.g., Sommerstein (1991) 196 and Dover (1968) 182. This passage is included in collections of imitations of Protagoras by Diels/Kranz (1952) §80 C 3 and Capizzi (1955) 214-215. 


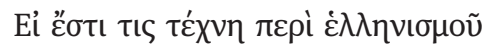

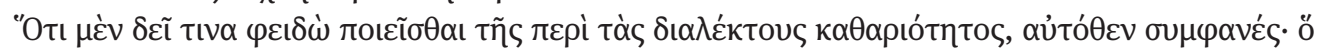

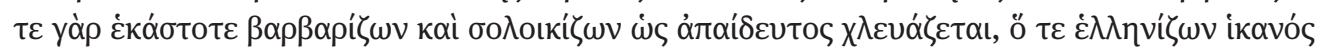

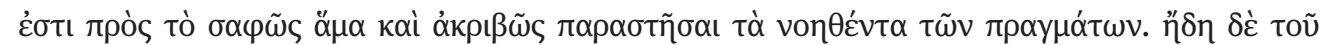

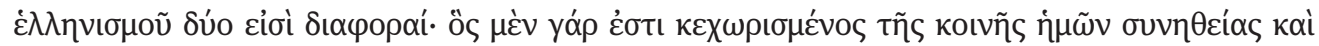

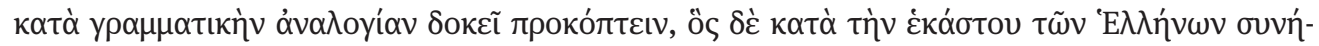

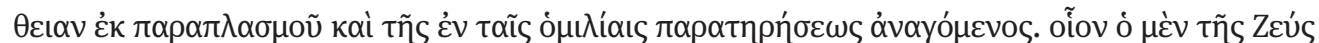

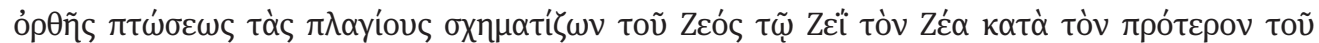

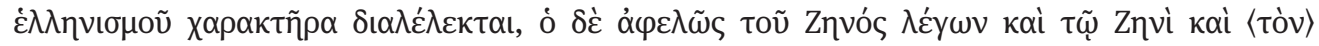

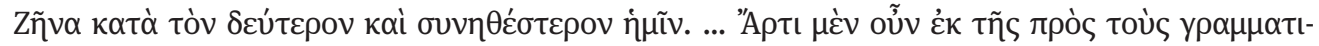

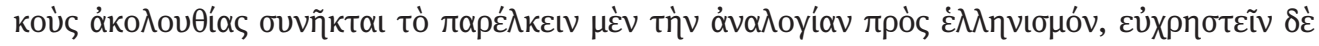

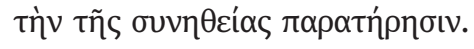

Whether there is an expertise about Hellenism

That one must take some care over purity of one's language is immediately obvious, since one who constantly commits barbarisms and solecisms is ridiculed as ignorant, while one who speaks good Greek is able to express clearly and accurately what he has in mind. Now there are two kinds of Hellenism, for one form is divorced from our common usage and seems to proceed according to grammatical analogy, while the other form accords with the usage of each of the Greeks and advances by assimilation and observation in conversation.

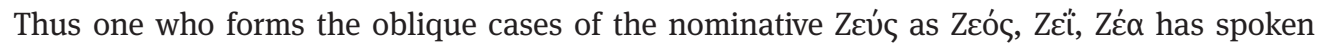

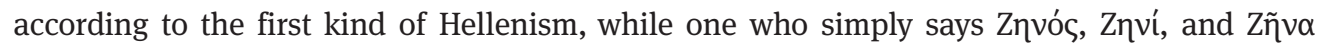
has spoken according to the second kind of Hellenism, to which we are more used. ... So it has just been deduced from the consequences of the grammarians' own argument that analogy is superfluous for Hellenism, while the observation of common usage is most useful. (Sextus Empiricus, Adversus mathematicos $1.176-77,209)^{4}$

The basis for claims of linguistic expertise here seems to be fundamentally the same as it was in Aristophanes' day: knowledge of rules based on analogy allows people to claim expert status. Those rules have been refined in the intervening centuries, and

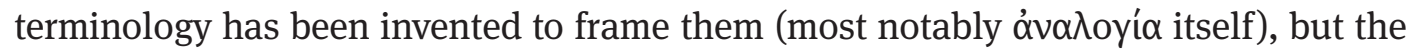
basic principle remains the same: linguistic experts are parodied as rejecting common usage in favour of weird creations that no-one actually uses but that ought to exist if the Greek language were more regular than it is. Again, the parody relies on the fact that the linguists' analogical rules produce results that seem preposterous to ordinary native speakers, but this time there is an additional complication.

The example Sextus chooses, the paradigm of Zzúc, is a complex one. A modern Hellenist might not see his 'regular' declension Zcós, Zcí, Zźa as the expected one

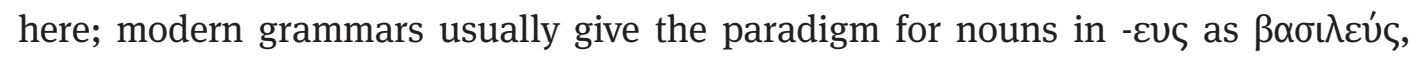

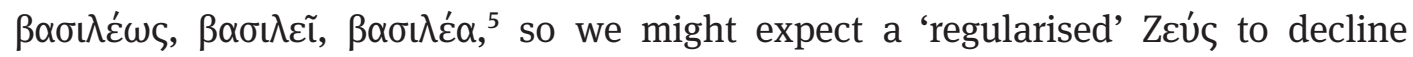

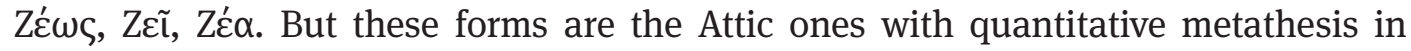
the genitive singular; most other dialects had other forms, and when ancient gram-

4 Translation from Blank (1998) 37-38, 42.

5 See Smyth (1956) §275; Goodwin (1894) §263. For ease of comparison with Sextus' argument, I give all paradigms in the ancient order: nominative, genitive, dative, accusative (followed by vocative if included). 
marians discussed the declension of Zcú s they largely agreed with Sextus about the way it would have declined if it had been regular. Passage 3, from the Byzantine writer Choeroboscus, is thought to come ultimately from Herodian, who lived in the second century $\mathrm{CE} .^{6}$

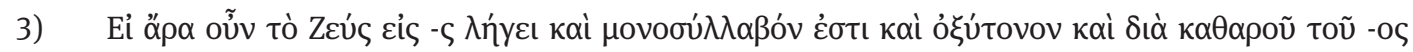

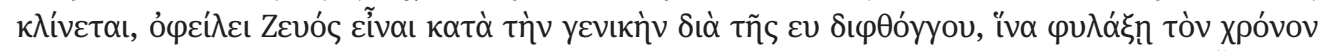

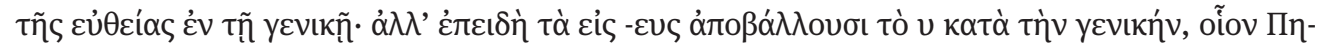

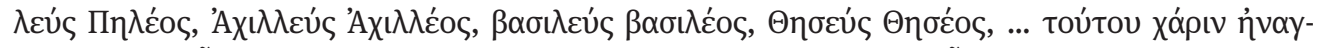

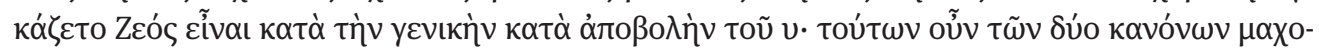

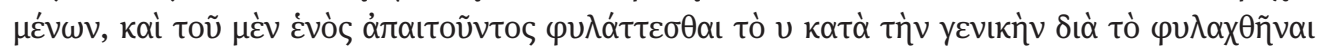

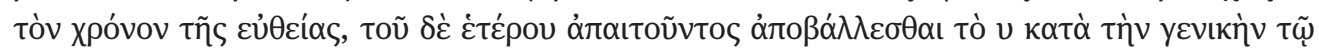

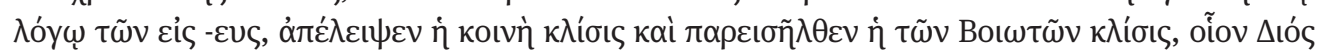

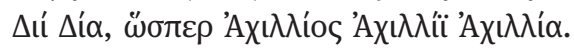

So therefore if Zzú ends in - $\varsigma$ and is a monosyllable and oxytone and is declined with a pure [i.e., preceded by a vowel] -os ending, it should be Zevós in the genitive with the diphthong $\varepsilon v$, so that it should keep the [vowel] length of the nominative in the genitive; but since nouns in

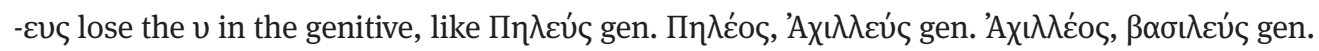

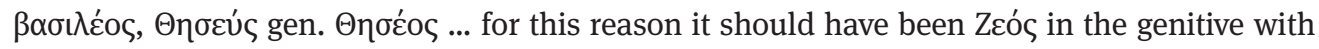
loss of the $v$. So since these two rules conflict, and one demands that it keep the $v$ in the genitive in order to keep the [vowel] length of the nominative, and the other demands that it lose the $v$ in the genitive on the principle of nouns in - $\varepsilon v \varsigma$, the common declension has failed and

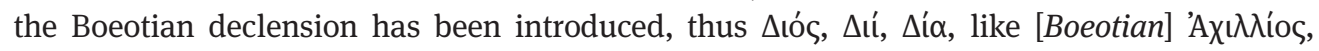

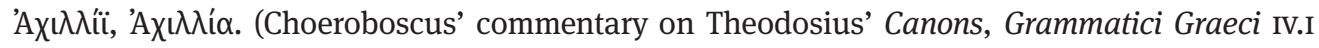
$214.15-20,23-29)^{7}$

Here Herodian is not suggesting that Zzúৎ should be declined like $\beta \alpha \sigma \iota \lambda \varepsilon v ́ \varsigma$ - he is

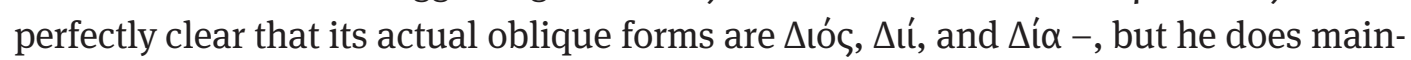
tain that if Zzú ing to another rule that it also does not follow. Theodosius (fourth/fifth century CE) has a similar discussion in the Canons, a set of prescriptive rules for the inflection of Greek words; he treats nouns in -عvৎ in canon 10.

4) Kavẃv ı'

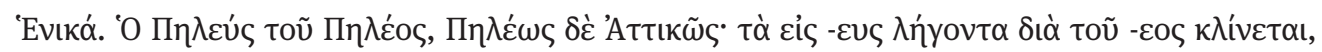

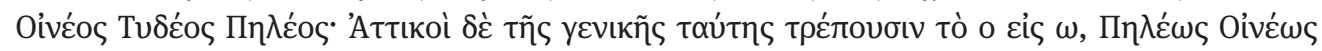

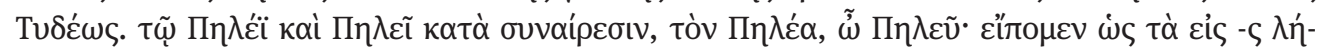

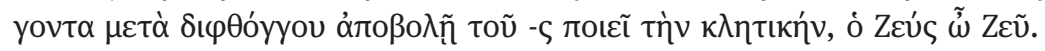

6 See Lentz's edition of Herodian (Grammatici Graeci III.II 674.25-40), where this passage is given as

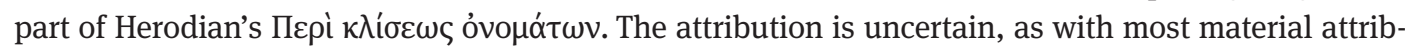
uted to Herodian; see Dyck (1993) and Dickey (2014). For additional discussions of Herodian's text and issues of scholarship, see the contribution by Stephanie Roussou in this volume.

7 Translations are my own unless otherwise noted. 
Rule 10

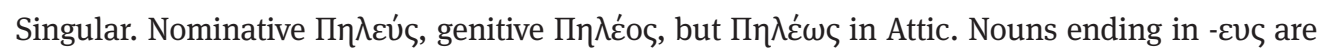

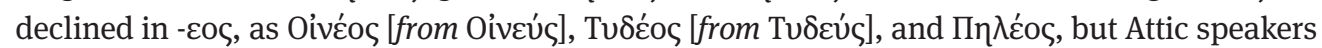

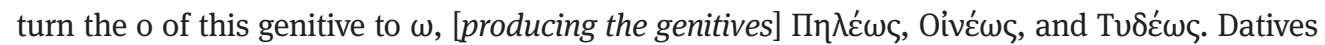
$\Pi \eta \lambda \varepsilon^{\prime i}$ and $\Pi \eta \lambda \varepsilon \tilde{~}$ with contraction; accusative $\Pi \eta \lambda \varepsilon \dot{\alpha} \alpha$, vocative $\Pi \eta \lambda \varepsilon \tilde{v}$. We said that nouns end-

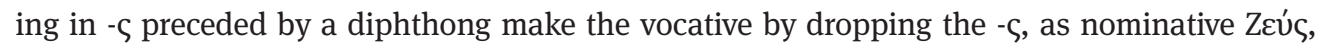
vocative Zcũ. (Grammatici Graeci IV.I 12.5-11; cf. Blank [1998] 209)

Here the Atticising paradigm that we normally learn is given, but only as an alterna-

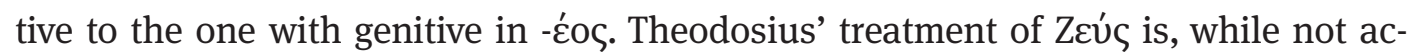
tually inaccurate, highly misleading for a student: by including Zzú sion of regular nouns in -عuৎ, and failing to point out that it does not in fact follow the rules given except in the one case mentioned, Theodosius strongly implies that it follows the rules. No doubt Theodosius knew perfectly well that it does not, but nevertheless if presentations like this were to be found in the works of genuine linguistic experts, Sextus' complaint about the ridiculous forms their rules would produce is not entirely unjustified.

Of course, neither of these passages predates Sextus, nor indeed do any of the other surviving discussions of the declension of Zcúc. ${ }^{8}$ But given the poor survival rate of early grammatical literature we would not expect to have such discussions from before the second century CE even if they had been common; most likely the irregularity of Zzús had already been pointed out long before Sextus' day. Sextus made a point of reading works of the experts he attacked, using their techniques of argumentation, and referring to points they debated, in order to illustrate his proficiency in the subject and therefore his authority to point out its drawbacks. ${ }^{9}$ It would therefore be entirely in keeping with his method to use an example from actual grammatical discussions here.

Therefore Sextus' first paradigm of Zcús actually makes perfect sense: it is what grammarians said that paradigm would have looked like if it had been regular. More

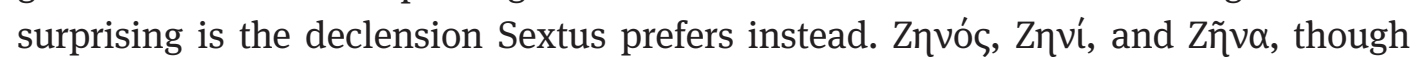
well attested (e.g., in Homer), were strictly poetic, and the normal oblique forms of Zzú s were unquestionably $\Delta$ iós, $\Delta \mathrm{i}$, and $\Delta$ ía. Sextus certainly knew this, for elsewhere he consistently employs the normal forms: ${ }^{10}$ why does he not give those forms here? Two answers are possible: the Znvós paradigm may have been preferred because it began with the same letter as the nominative Zcús and therefore looked

8 These include Choeroboscus, Epimerismi in Psalmos p. 72.17 Gaisford; Sophronius, Excerpta ex Joannis Characis commentariis in Theodosii Alexandrini canones (Grammatic Graeci IV.II 390.30); Epimerismi Homerici $\zeta 3.6$ Dyck; Etymologicum Gudianum $\zeta$ p. 230.4 Sturz; etc. They appear all to be related to one another and to Herodian's and Theodosius' discussions.

9 Sluiter (2000a).

10 sós Adversus mathematicos 2.105, 5.29, 5.34, 5.36, 7.265, 9.36, 9.67, Pyrrhoniae hypotyposes 1.189; $\Delta \mathrm{u}$ Adversus mathematicos 1.290, Pyrhoniae hypotyposes 3.224; $\Delta$ ía Adversus mathematicos 3.6, 3.104, 5.32, 6.3, 7.240, 7.445, 8.308, 8.375, 8.479, 9.115, Pyrrhoniae hypotyposes 1.50, 1.161, 2.141. 
more regular (in which case Sextus would have been partially conceding the point that regularity makes correctness), or it may have been preferred precisely because it was poetic. We shall return to this point later.

Both Aristophanes and Sextus make it very clear that they, as non-experts, saw linguistic experts as characterised by knowledge of rules based on regularities, i.e. analogy. The writings of actual linguistic experts tend to confirm this picture. Hero-

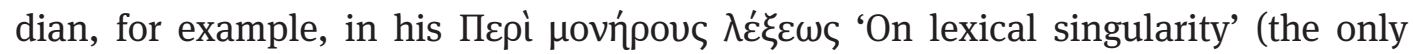
work of Herodian to survive intact and therefore the only one to preserve discussions of this type) presents analogy as the key to understanding Greek and portrays Herodian himself as the champion of analogy. ${ }^{11}$ In his other, fragmentary works Herodian implicitly makes the same point by constantly using rules based on analogy to argue for the correctness or incorrectness of particular variants. Passage 5 is typical:

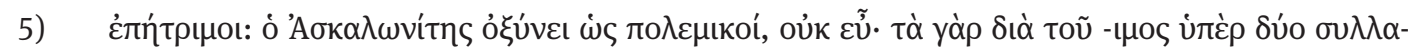

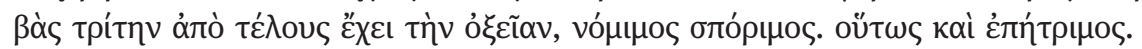

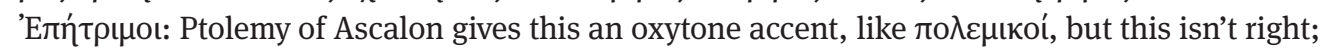
for words in - $\mu$ os more than two syllables long have an acute on the third syllable from the

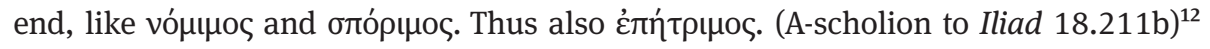

Herodian's father Apollonius Dyscolus, who also wrote in the second century CE, states that his goal in formulating the rules of syntax is to show the extent of regularity in Greek, as passage 6 illustrates.

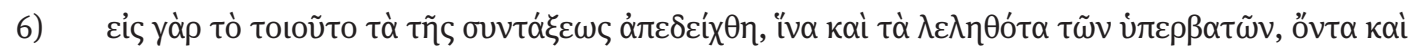

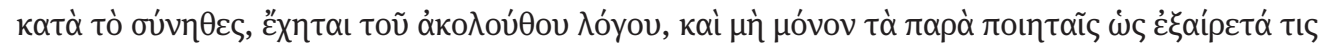

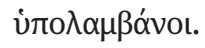

For the rules of syntax have been demonstrated for just this purpose, so that even the unnoticed disturbances, which exist even in normal usage, may participate in the rule of regularity, and lest someone assume that only those disturbances used by the poets are exceptional. (Apollonius Dyscolus, Syntax 183.14-16 = II.77) $)^{13}$

Most of the time, the correctness the grammarians cared about was a correctness of authenticity in the language of Homer or another early author; for example, Herodian's point in passage 5 is that in reciting the Iliad one should use a particular accen-

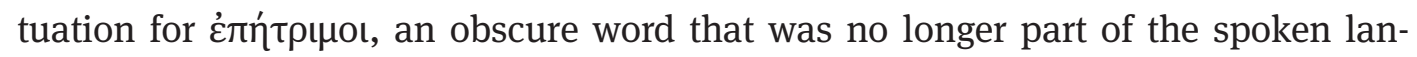

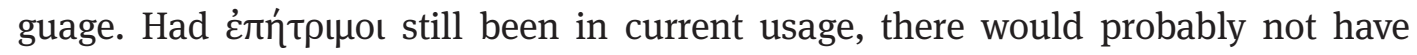
been a question about how to accent it, since native speakers would simply have known which syllable bore the accent. ${ }^{14}$ This correctness is different from the kind

11 Suiter (2011).

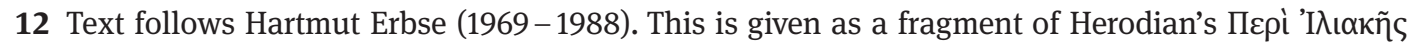
$\pi \rho \circ \omega \delta_{i} \alpha_{\alpha}$, by Lentz in Grammatici Graeci III.II 107.13-15.

13 Translation from Blank (1994) 158-159.

14 Although there were some changes in the nature of the Greek accent after the Classical period most significantly, the distinction between acute and circumflex ceased to be audible - the position 
of correctness envisioned by Sextus or Aristophanes in their parodies of linguistic experts: the parodies depict experts making prescriptive judgements about contemporary usage. In general, the surviving fragments of the Alexandrian grammarians and other early linguistic experts do not show much evidence of interest in prescribing contemporary usage, but there are a few passages in which ancient grammarians do look as though they are being prescriptive - and using analogy to support their judgements. In passage 7, for example, Apollonius seems to use analogy to argue that some Greek speakers are wrong in their pronunciation of ảvekás.

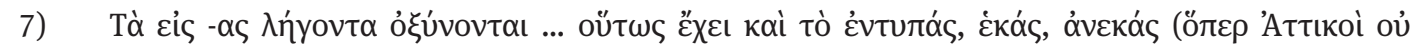

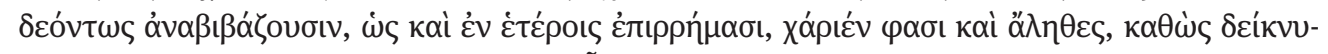

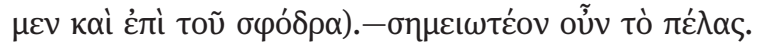

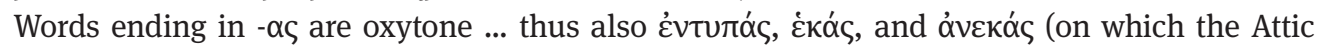

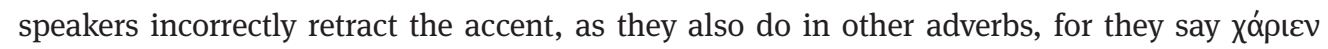

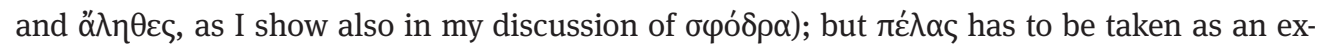
ception. (Apollonius, Dyscolus, De adverbiis 160.19-23)

In this passage Apollonius is not in fact doing what the parodies say that linguistic experts do: he is not using a rule derived from analogy to argue that what everyone does is wrong. The accent of $\pi \varepsilon ́ \lambda \alpha \varsigma$ does not fit the analogical rule, and Apollonius simply labels it as an exception rather than prescribing the analogically more regular

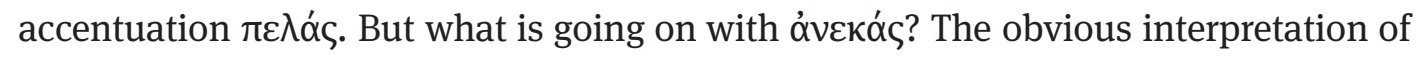
Apollonius' words here is that when one group of Greek speakers has one accentuation and another group has another accentuation, only one of them can be right, and analogy will show which one that is. This may not be exactly what Apollonius really meant, for like all Greek grammarians he was well aware of the differences between Greek dialects. An Attic, Doric, or Aeolic feature not shared by the other dialects was not normally considered 'right' or 'wrong' in an abstract sense, but simply seen as a dialect feature. It would be appropriate in text using that dialect, and inappropriate in text using a different dialect. So perhaps Apollonius' oủ $\delta \varepsilon o ́ v \tau \omega \varsigma$ did not really mean 'incorrectly'; perhaps what he really meant was something closer to 'exceptionally'. ${ }^{15}$ Nevertheless, a reader could not be blamed for interpreting this passage as saying that the analogical rule shows that the Attic accentuation is wrong; statements like this probably helped create the image of a linguistic expert parodied by Sextus.

Passage 8 is very similar: it appears to use analogical rules to decide which of two groups of Greek speakers is right, though again this may not be quite what the writer intended to convey. This passage, however, is considerably earlier, coming

of the accent was not normally affected. Most ancient words that survive into modern Greek still have the accent on the same syllable as in the fifth century BCE. Native Greek speakers of all periods, therefore, rarely had difficulties knowing which syllable to accent when using ancient words that remained part of the living language.

15 I owe this idea to Philomen Probert (personal communication). 
from the first century BCE; as such it demonstrates that this type of statement was not new in the second century CE, but based on a long tradition. ${ }^{16}$

8) ع̋

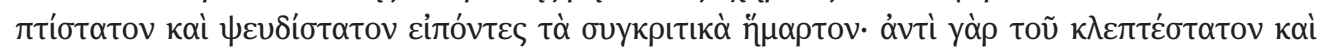
$\psi \varepsilon v \delta \varepsilon ́ \sigma \tau \alpha \tau o v$.

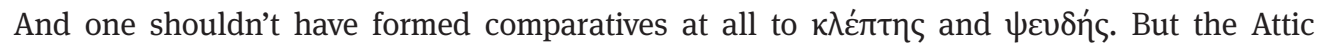
speakers, who said $\kappa \lambda \varepsilon \pi \tau i ́ \sigma \tau \alpha \tau o v$ and $\psi \varepsilon v \delta i ́ \sigma \tau \alpha \tau o v$, were wrong about the comparatives. For they should have been $\kappa \lambda \varepsilon \pi \tau \varepsilon \dot{\sigma} \sigma \alpha \tau o v$ and $\psi \varepsilon v \delta \varepsilon \dot{\sigma} \sigma \alpha \tau o v$. (Philoxenus fr. 339 Theodoridis, quot-

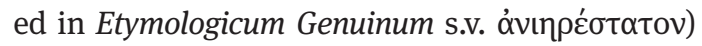

It is notable that in both passage 7 and passage 8 the usage apparently characterised as not being right is that of Attic speakers. In passage 9 we get a different kind of analogical explanation of an Attic variant: here Attic is clearly stated to have its own, separate regularities, making it different from but not necessarily better or worse than the non-Attic forms. Unfortunately, this passage is hard to date; at least some of the basic ideas evidently come from the first-century BCE scholar Trypho, but they were reformulated in the early second century CE and then epitomised under the name 'Ammonius'.

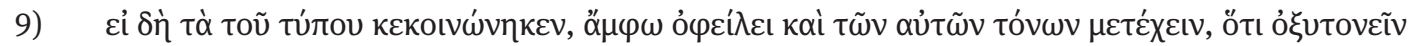

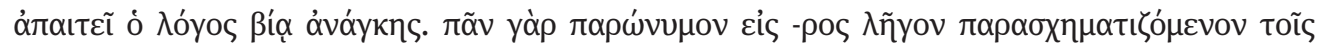

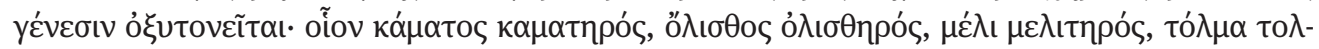

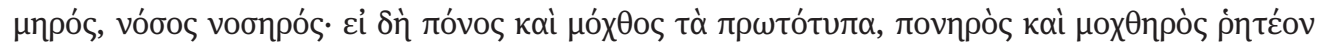

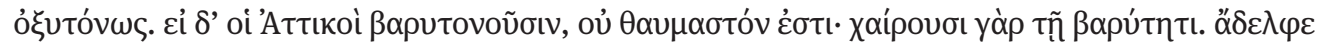

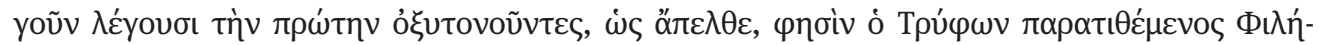

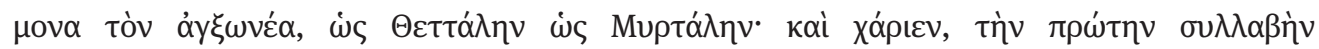

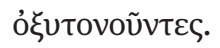

So if they share the same original form, they should also both share the same accents; the argument demands by necessity that they be oxytone. For every derivative ending in -pos formed

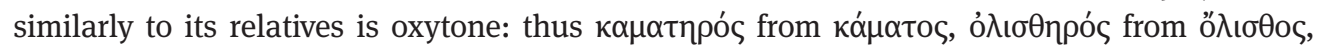

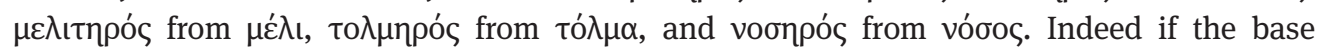

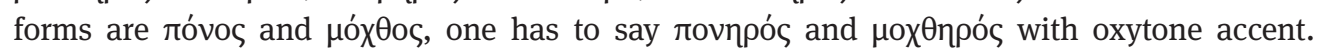
And if the Attic speakers give them a recessive accent, it's not surprising, for they often give things recessive accents. For example they say $\alpha \delta \delta \varepsilon \lambda \varphi \varepsilon$, putting an acute accent on the first syl-

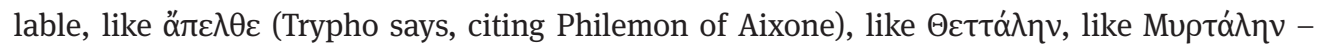
and $\chi \alpha$ ópıvv, to which they give an acute on the first syllable. (Ammonius, ed. Nickau (1966), entry $405.8-19$ = p. 116; cf. Trypho frag. 2.9)

The type of comment seen in examples 7-9, in which Attic has a status no higher than other dialects, reflects a fundamentally pre-Atticist viewpoint. Once Classical Attic was prescribed as the standard for judging contemporary written Greek,

16 Although generally speaking direct evidence for the reasoning of scholars earlier than the first century BCE is non-existent, note Ax's discussion of the possibility that Aristophanes of Byzantium was an 'Analogist' (Ax 1990). 
'Attic' became virtually synonymous with 'correct', making statements such as the ones just quoted difficult for later readers to understand. ${ }^{17}$

\section{Linguistic expertise based on knowledge of the Attic literary canon}

Analogy was not the only criterion on which linguistic expertise could be based. Although the famous feud between Analogy and Anomaly is now thought never to have existed, ${ }^{18}$ and anomaly would in any case have been very difficult to use as the basis for a claim of either correctness or expertise, a number of genuine criteria have been identified. ${ }^{19}$ Only one of these, however, comes close to rivalling analogy's status as the basis of linguistic expertise, and that is attestation in the Attic literary canon. Experts relying on this criterion are parodied even more often than ones using analogy, and a number of these parodies can be found in the second-century CE writer Lucian. Lucian was of course an accomplished Atticist himself, but he vigorously attacked rival speakers both for excessive archaism and for making mistakes. When in the course of such attacks Lucian explains why something should be considered right or wrong, he never uses the type of analogical arguments we have so far seen; instead he bases claims to correctness on attestation in classical authors. This is what linguistic Atticism was fundamentally about: if a word or usage could be found in a good Classical or Archaic author, it was right, and if not, it was wrong. Now of course not all good Classical authors wrote in what we would call the Attic dialect, but during the Roman period the term 'Attic' came to be extended to include all Classical and Archaic authors whose style one might want to imitate, regardless of their actual dialect. This is how Homer came to be considered an Attic author. ${ }^{20}$

In passage 10, from the Lexiphanes, Lucian makes the point that a rival 'speaks like a foreigner': this man's excessive use of Attic archaisms makes his speech appear not Attic at all. Later in the same work Lucian shows, point by point, that his opponent misuses the obscure words of which he is so proud: the words themselves may be Classical Attic, but the meanings in which they are used are unattested in the Attic canon, and therefore wrong (passage 11).

17 Probert (2011).

18 For Varro's misrepresentation of grammatical debate and the non-existence of a school of Anomaly, see Blank (1994) 152-58. There are no appeals to Anomaly as a criterion of correctness in ancient linguistic discussions. See Siebenborn (1976).

19 Siebenborn (1976) lists the following in addition to analogy: literary tradition, usage, etymology, and dialect (that is, the comparison of forms in different dialects to shed light on underlying patterns), plus a few Latin criteria that are not attested in Greek.

20 Cf. Dickey (2007) 98. 


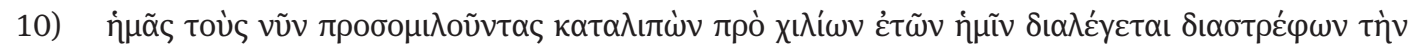

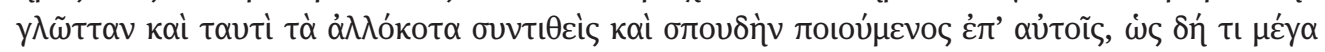

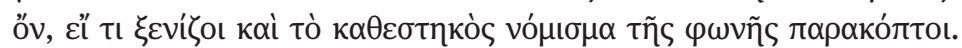

Leaving behind us who are talking to him now, he talks to us like a thousand years ago, twisting up his tongue and putting together these monstrous things and being very serious about them, as if it were something great if he should speak like a foreigner and debase the established currency of our language. (Lucian, Lexiphanes 20)

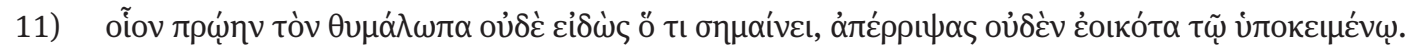

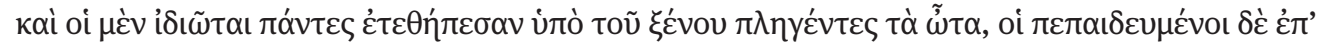

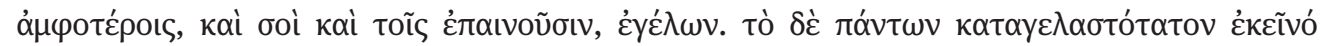

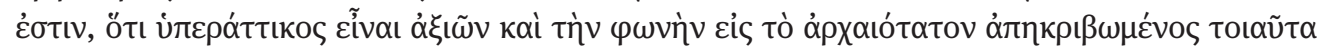

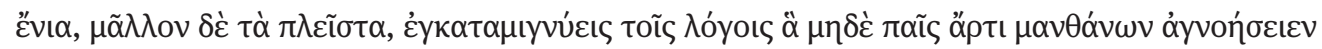

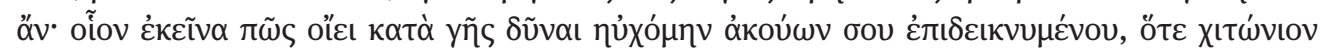

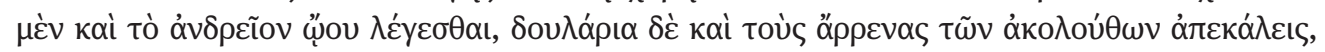

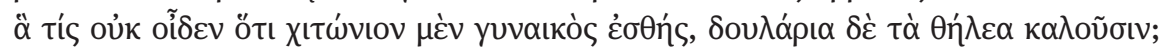

Just as recently you threw in the word $\theta v \mu \alpha \dot{\lambda} \lambda \omega \pi \alpha$, having no idea what it means, when it had no connection to what you were trying to say. And the laymen were all astonished when their ears were struck by this foreign term, but the educated men were laughing both at you and at those who praised you. And the most ridiculous thing of all is that when you want to be hyperAttic, and have carefully modelled your speech into the most archaic form possible, you mix in with your words some, or rather many, mistakes that not even a child just beginning to study would make. For example, how I prayed to sink beneath the earth when I heard you revealing

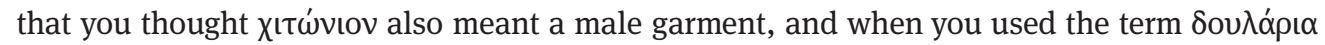

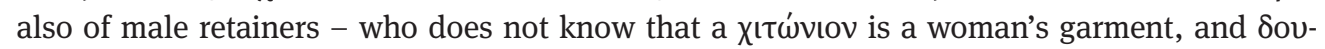
$\lambda \alpha$ ópı refers to females? (Lucian, Lexiphanes 24-25)

Athenaeus, who wrote in the late second and early third centuries CE, also provides a sustained parody of this sort of appeal to attestation in the person of a character

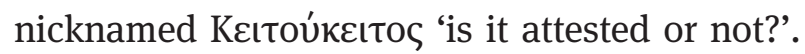

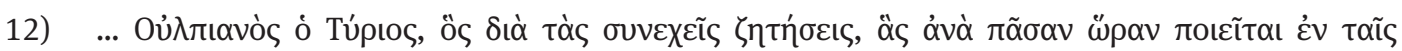

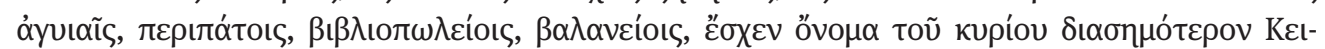

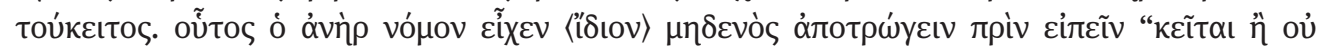

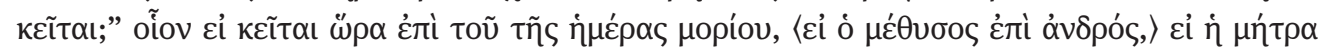

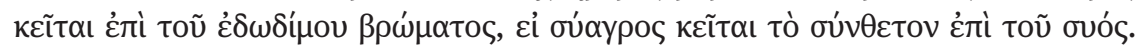

... Ulpian the Tyrian, who on account of the constant questions that he asks at every hour in

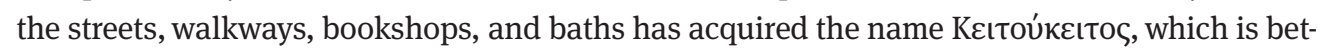
ter known than his real one. This man had the idiosyncratic custom of not eating anything before asking, 'Is it attested or is it not attested?' For example, asking whether 'hour' is attested for a part of the day, whether 'drunk' is attested applied to a man, whether 'paunch' is attested for the edible food, whether the compound word 'wild-boar' is attested for a pig. (Athenaeus, Deipnosophistae 1.2d-e)

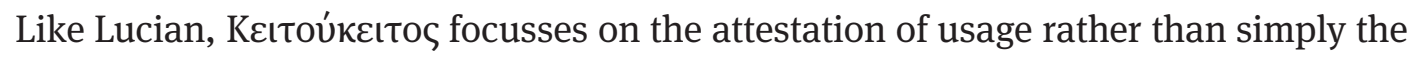
attestation of vocabulary. The latter was comparatively easy to ascertain in the second century, when a plethora of Atticistic lexica meant that one only had to look words up in a dictionary to find their ages, but the former required real knowledge of the Classical canon and was therefore the area on which disputes about expertise 


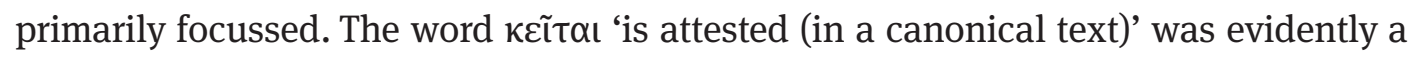
key technical term in this context, embodying the concept of attestation in the Classical canon. It is widely used by writers on language in the same sense as by Athe-

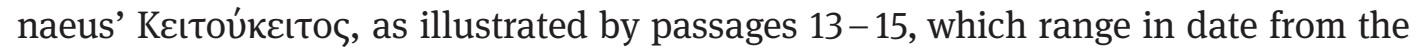
second to the fifth century CE.

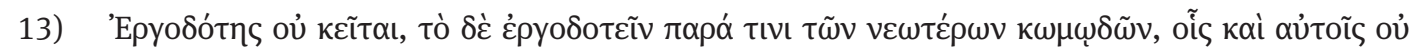

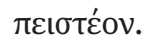

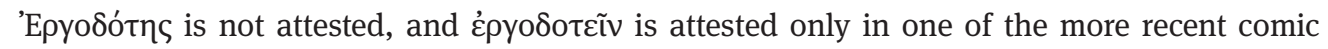
poets, whom (as a group) one should not trust. (Phrynichus, Eclogae 322)

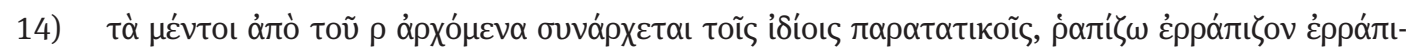

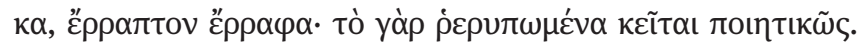

But the perfects that begin with $\rho$ - have the same beginning as their own imperfects, as [pre-

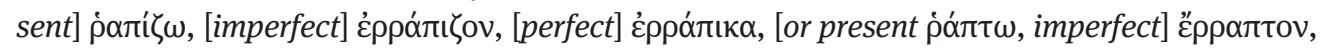
[perfect] है $\rho \rho \alpha \rho \alpha$; for [perfect] $\dot{\rho} \varepsilon \rho u \pi \omega \mu \varepsilon \dot{v} \alpha$ is attested [only] in poetry. (Theodosius, Grammatici Graeci Iv.I 48.8)

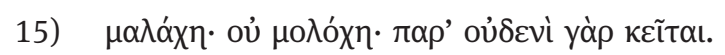

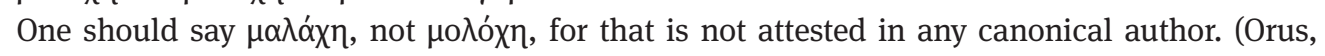
fragment 95 in Alpers 1981)

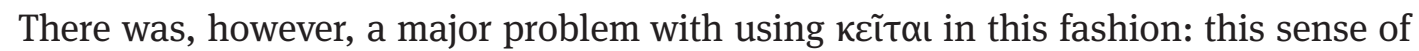

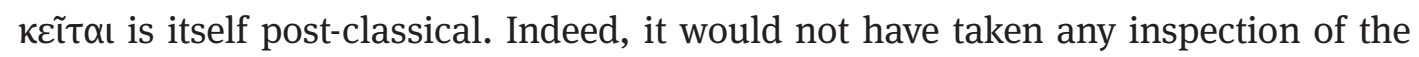
Classical canon to realise that, for the Classical canon itself must by definition be a post-Classical concept, and the concept of attestation in the Classical canon cannot predate the concept of the canon. Many educated Greek speakers were well aware of this fact and therefore avoided the term; Lucian, for example, never uses кعĩ $\alpha$ เ to mean 'attested in the canon'. Many others, however, used the term as freely as Athe-

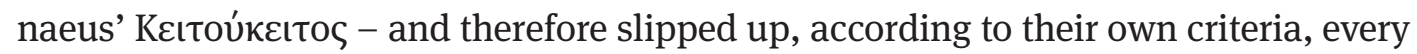
time they did so. Athenaeus was no doubt aware of this ironic situation and expected

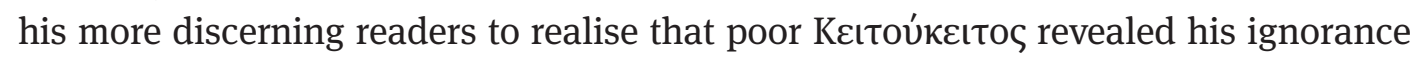
every time he asked a learned question.

The earliest examples of кعĩ $\alpha$ in this sense probably come from the first century $\mathrm{CE}$, if in fact it is to be found in passages 16 and 17. Passage 16 is a fragment without context; passage 17 is one of a number of similar examples from Erotian's lexicon of Hippocratic words.

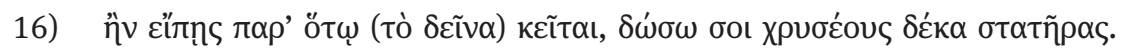

If you can tell me in what author that is attested, I'll give you ten gold staters. (Heraclides Ponticus Junior, fragment 1 in Heitsch (1964) 41)

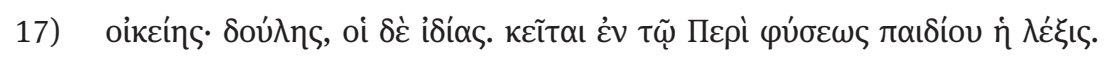

'Oikzíns means 'of a female slave', but others say that it means 'personal [gen. sing. f.]'. The word is attested in the work entitled 'On the nature of the child'. (Erotian 101.4 in Nachmanson 1918) 
The first century is therefore likely to be the period in which the concept represented by кєі̃ $\alpha$, attestation in the Classical canon, first gained traction as a criterion of expertise. This concept cannot, however, have grown very influential by the time of Sextus Empiricus, since his attack on linguistic expertise focusses exclusively on analogy and does not attack the Atticists - who, as both Lucian and Athenaeus show, made excellent targets for ridicule once their movement was well established.

\section{The unseen role of vernacular Greek}

We see, therefore, two shifts in Greek thinking about linguistic expertise. The first occurred in the fifth century BCE, when the concept of the linguistic expert first arose: at that point claims to linguistic expertise were based on observation of regularities and extrapolation of rules from them. The second shift occurred in the second century CE, when the defining characteristic of the linguistic expert ceased to be knowledge of analogy and began to be knowledge of the Attic canon instead. The grammarians themselves did not stop using analogy, since nothing ever really disappeared from the Greek grammatical tradition. But they and their analogical rules ceased to be seen by others as the paradigm of linguistic expertise. After Sextus Empiricus, laymen thinking about linguistic experts had a stereotype of an expert in the Classical Attic literary canon, rather than a stereotype of an expert in analogical rules. How did this change come about?

The shift is unlikely to have come from the experts themselves, not only because they had a well-established vested interest in continuity but also because expert status is conferred primarily by outsiders. It is not an individual's possession of special knowledge, but the recognition by others that that individual's knowledge is special, that makes someone an expert. ${ }^{21}$

21 There is of course the complication that in some circumstances a society assigns expert status in a particular area to a clearly specified group, which is entrusted with the responsibility for deciding whom to admit to their group. This is the case with, for example, the licensing of doctors and electricians today: only doctors can decide who counts as a doctor, and only electricians can decide who counts as an electrician. But it is society as a whole, not the experts themselves, that gives validity to those licensing decisions: if laymen (such as those making the laws that forbid practising medicine without a licence) did not care whether or not someone was licensed to practice medicine, such licensing would have little practical impact. Even today, many skilled professions are not regulated in the same way: in England, for example, anyone can claim to be a plumber, and any non-plumber can judge whether that claim is accurate by hiring the alleged plumber to fix a plumbing problem. In antiquity most fields of expertise operated as plumbing does today, for no bodies of experts were organised to the extent of having meaningful licensing powers. It is clear that claims to linguistic expertise were disputed by other experts - that is what is going on in Lucian's Lexiphanes - but without an appointed authority to judge such disputes, they could have no clear process of resolution. Ultimately each person, no matter how much or how little he or she knew about the subject, would have had to make up his or her own mind about whom to trust as an expert. 
During the period between the fifth century BCE and the second century CE ordinary Greeks, those who were not linguistic experts, experienced a significant change in their relationship to the Greek language. In the Classical period Athenians simply spoke and wrote their native language and did not worry about linguistic rules unless they happened to encounter someone like Protagoras - and even then they do not appear to have changed their linguistic practice to fit his rules. But by the start of the second century CE even Sextus Empiricus, who did not think there was any such thing as an expert, had to begin his attack on grammar with an acknowledgement that speakers needed to take care to speak good Greek; those who did not would be ridiculed for ignorance (passage 2). The everyday spoken language had changed gradually over time, as living languages always do, and after more than half a millennium the accumulated changes were significant; meanwhile the written standard had changed much less. In consequence, even before the rise of Atticism a major gap had opened up between the Greek that speakers were supposed to produce and the Greek that they found it easy to produce.

Although these changes in Greek came in all aspects of the language, from phonetics through morphology and the lexicon to syntax, the morphological changes were particularly striking because of their consistent direction: they tended towards regularisation. The complex irregularities of Classical Greek inflection underwent wholesale simplification and regularisation, as evidenced by the usage in documen-

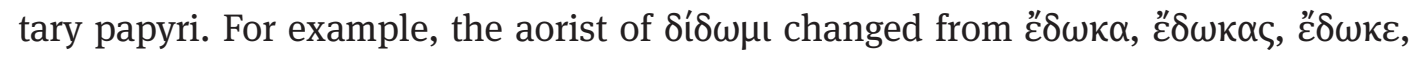

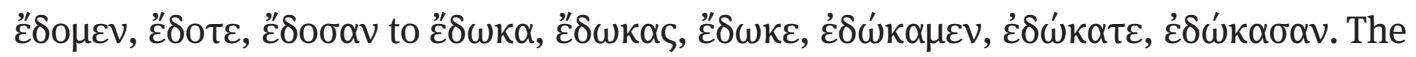

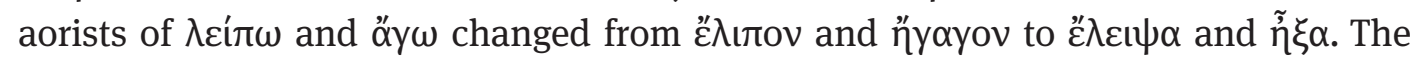

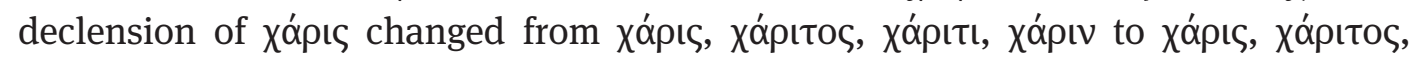

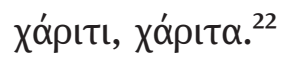

Such changes would naturally have led ordinary Greek speakers to have less and less respect for analogy. Linguistic communities tend to consider 'good' the speech of the people who have high status in the community, and 'bad' the speech of the people who have low status. In the Roman empire there was a considerable connection between status and education, and therefore it was more often the low-status people who used the newer, more regular forms. Now the grammarians themselves were skilled in the application of analogy and would not have used it to justify new forms used by low-status members of the community as opposed to the older, less regular forms used by the more prestigious speakers. But whatever the experts actually did, laymen could see for themselves that the principle of analogy was not one that worked for what they wanted.

What they wanted, what they valued, was expertise that helped them with the linguistic challenges they faced. The first of these was to read and understand the Classical and Archaic texts taught in schools: children learned to read on Homer during the Roman empire, just as they had done in Classical Athens, but Homer had be-

22 See Gignac (1981) passim. 
come considerably more difficult during the intervening centuries. The second challenge was to produce correct Greek themselves, in writing and under some circumstances also in speech. A person who knew how to read, understand, and produce the kind of Greek that the non-experts aspired to master was the type of person they would acknowledge to be a linguistic expert.

Indeed, it is possible that this attitude on the part of non-experts was one of the catalysts for the rise of Atticism. Seeing a social and economic opportunity in the growing demand for linguistic expertise based on knowledge of the Classical canon, educated Greek speakers marketed themselves as experts of this type. Competition for this expert status (as evidenced by the rivalries between Lucian and other contemporary speakers) rapidly developed, leading to a sort of arms race in linguistic archaism. Then the production of aids such as the Atticising lexica raised the standards still further by making it easier for anyone to produce superficially educated-sounding Greek without actually mastering the entire canon. That in turn led the competition to focus on ever-more-difficult linguistic features, such as the attestation of particular usages rather than of words.

This situation may also explain Sextus' bizarre choice of the poetic Znvós paradigm rather than the usual $\Delta$ ós one in passage 2 . As noted earlier, it is possible that Sextus preferred Znvós precisely because it was not what people normally used, but rather a Homeric paradigm. At the beginning of the second century CE Homeric forms had a growing cachet, and the ability to produce them was no doubt seen as a desirable form of expertise. Sextus' point that one does not need linguistic experts if one just pays attention to usage may have been greatly strengthened by the implicit demonstration that by paying attention to (Homeric) usage one can, without relying on experts, produce a fancy Homeric paradigm of Zzúc. The Atticists were clearly not a significant enough group of experts for Sextus to consider them worth attacking, but that does not mean that he was completely unaware of their movement. Perhaps he found an implicit appeal to their ideas useful in his attempts to discredit the established linguists. If this is what was going on, we can see in passage 2 an early skirmish in the ultimate triumph of Atticism over analogy. 


\section{Bibliography}

Adams (2018): Adams, S. A. 'Where's Rome? A Possible Roman Parallel to the Translation of the Septuagint in the Letter of Aristeas'. In G. Xeravits and G. Schmidt (eds.), Figures Who Shape Scriptures, Scriptures That Shape Figures: Essays in Honour of Benjamin G. Wright III. DCLS 40. Berlin: de Gruyter, $197-210$.

Adler (1938): Adler, A. 'Urbano fra Belluno’s Graeske Haandskrifter’. Nordisk Tidskrift för Bok- och Biblioteksväsen 25, 73-80.

Ahl (1971): Ahl, Frederick. 'Lucan's De incendio urbis, Epistulae ex Campania and Nero's Ban'. TAPhA 102, 1- 27.

Aitken (2011): Aitken, James K. 'The Literary Attainment of the Translator of Greek Sirach'. In J.-S. Rey and J. Joosten (eds.), The Texts and Versions of the Book of Ben Sira: Transmission and Interpretation. JSJSup 150. Leiden: Brill, 95-126.

Aitken (2014): Aitken, James K. No Stone Unturned: Greek Inscriptions and Septuagint Vocabulary. CSHB 5. Winona Lake, IN: Eisenbrauns.

Aitken (2016): Aitken, James K. 'The Septuagint and Egyptian Translation Methods'. In W. Kraus, M.N. van der Meer, and M. Meiser (eds.), XV Congress of the International Organization for Septuagint and Cognate Studies: Munich, 2013. SBLSCS 64. Atlanta: SBL Press, 269-93.

Albeck (1988): Albeck, Hanoch. The Six Orders of the Mishnah: Seder Zera'im [Hebrew]. Tel Aviv: Dvir.

Alberti (1972-2000): Alberti, G. B. Thucydidis Historiae, I-III. Rome: Istituto Poligrafico dello Stato.

Albl (1999): Albl, M. C. 'And Scripture Cannot Be Broken': The Form and Function of the Early Christian Testimonia Collections. NovTSup, 96. Leiden: Brill.

Albl (2016): Albl, M. C. 'The Testimonia Hypothesis and Composite Citations'. In S.A. Adams and S.M. Ehorn (eds.), Jewish, Graeco-Roman, and Early Christian Uses, vol. 1 of Composite Citations in Antiquity. LNTS 525. London: Bloomsbury T\&T Clark, 2016, 182-202.

Alexander (1990): Alexander, Loveday. 'The Living Voice: Scepticism Towards the Written Word in Early Christian and in Graeco-Roman Texts'. Journal for the Study of the Old Testament Supplement Series 87, 221- 47.

Alpers (1975): Alpers, Klaus. 'Review of Contributions to a History of Alphabetisation in Antiquity and the Middle Ages, by Lloyd W. Daly'. Gnomon 47, 113-18.

Alpers (1981): Alpers, Klaus. Das attizistische Lexikon des Oros: Untersuchung und kritische Ausgabe der Fragmente. Berlin: de Gruyter.

Alpers (2004): Alpers, Klaus. 'Die griechischen Orthographien aus Spätantike und byzantinischer Zeit. Anmerkungen zu einer Publikation'. Byzantinische Zeitschrift 97, 1-50.

Ammirati (2010): Ammirati, Serena. 'Per una storia del libro latino antico: osservazioni paleografiche, bibliologiche e codicologiche sui manoscritti latini di argomento legale dalle origini alla tarda antichità'. Journal of Juristic Papyrology 40, 55-110.

Ammirati (2013): Ammirati, Serena. 'The use of wooden tablets in the ancient Graeco-Roman world and the birth of the book in codex form: some remarks'. Scripta: An International Journal of Codicology and Paleography 6, 9-15.

Ammirati (2015a): Ammirati, Serena. Sul libro latino antico. Ricerche bibliologiche e paleografiche. Pisa-Rome: Fabrizio Serra Editore.

Ammirati (2015b): Ammirati, Serena. 'Leggere Cicerone in Egitto: osservazioni paleografiche (e filologiche)'. In Paolo De Paolis (ed.), Dai papiri al XX secolo. L'eternità di Cicerone. Atti del VI Simposio ciceroniano. Arpino, 9 maggio 2014 (XXXIV Certamen Ciceronianum Arpinas). Cassino: Cassino University Press, 13-15. 
Ammirati (2017): Ammirati, Serena. 'Il paratesto nei manoscritti giuridici di origine romana'. Segno e Testo 15, 247-60.

Ammirati (forthcoming): Ammirati, Serena. 'Il codice veronese delle Institutiones di Gaio. Paleografia e codicologia'. In Ulrike Babusiaux and D. Mantovani (eds.), Le istituzioni di Gaio: avventure di un best-seller: Trasmissione, uso e trasformazione del testo. Pavia: Pavia University Press.

Anderson (1993): Anderson, Graham. The Second Sophistic: A Cultural Phenomenon in the Roman Empire. London: Routledge.

Armstrong (2008): Armstrong, R. 'Classical Translations of the Classics: The Dynamics of Literary Tradition in Retranslating Epic Poetry'. In A. Lianeri and V. Zajko (eds.), Translation and the Classic: Identity as Change in the History of Culture. Oxford: Oxford University Press, $169-202$.

von Arnim (1895): von Arnim, Hans. 'Apollonios von Tyros [94]'. RE 2.1, 146.

Asmis (2001): Asmis, E. 'Basic Education in Epicureanism'. In Y.L. Too (ed.), Education in Greek and Roman Antiquity. Leiden: Brill, 209-39.

Aufrère et al. (2014): Aufrère, S. H., P. S. Alexander, and Z. Pleše, editors. On the Fringes of Commentary: Metatextuality in Ancient Near Easter and Ancient Mediterranean Cultures. OLA 232. Leuven: Peeters.

Ax (1990): Ax, Wolfram. 'Aristophanes von Byzanz als Analogist: zu Fragment 374 Slater (= Varro, de lingua Latina 9,12)'. Glotta 68, 4-18.

Badoud (2002): Badoud, Nathan. 'La table claudienne de Lyon au XVle siècle'. Cahiers du Centre Gustave Glotz 13, $169-95$.

Baldwin (1983): Baldwin, Barry. Suetonius. Amsterdam: Hakkert.

Barclay (1996): Barclay, J. M. G. Jews in the Mediterranean Diaspora: From Alexander to Trajan (323 BCE-117 CE). Edinburgh: T\&T Clark.

Bardon (1952): Bardon, Henry. La littérature latine inconnue. Vol. 1: L'époque républicaine. Paris: Klincksieck.

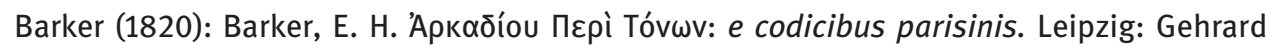
Fleischer.

Barnes (1999): Barnes, Jonathan. 'Aristotle and Stoic Logic'. In Katerina lerodiakonou (ed.), Topics in Stoic Philosophy. Oxford: Oxford University Press, 23-53.

Baron (2013): Baron, Christopher A. Timaeus of Tauromenion and Hellenistic historiography. Cambridge: Cambridge University Press.

Barr (1979): Barr, J. 'The Typology of Literalism in Ancient Biblical Translations'. Mitteilungen des Septuaginta-Unternehmens, 15. Gottingen: Vandenhoeck \& Ruprecht.

Bassnett (2014): Bassnett, S. Translation Studies. Fourth edition. London: Routledge.

Bayer (2002): Bayer, Karl. Suetons Vergilvita: Versuch einer Rekonstruktion. Tübingen: Gunter Narr. Beaulieu (2006): Beaulieu, Paul-Alain. 'Berossus on Late Babylonian History'. Oriental Studies, $116-49$.

Becker (2006): Becker, Adam H. Fear of God and the Beginnings of Wisdom. The School of Nisibis and the Development of Scholastic Culture in Late Antique Mesopotamia. Philadelphia, PA: University of Pennsylvania Press.

Becker (2010): Becker, Adam H. 'The Comparative Study of 'Scholasticism' in Late Antique Mesopotamia: Rabbis and East Syrians'. AJS Review 34, 91-113.

Bernstein (2005): Bernstein, M. J. “"Rewritten Bible”: A Generic Category Which Has Outlived Its Usefulness?’. Textus 22, $169-96$.

Biville (2002): Biville, F. 'The Graeco-Romans and Graeco-Latin: A Terminological Framework for Cases of Bilingualism'. In J.N. Adams, M. Janse, and S. Swain (eds.), Bilingualism in Ancient Society: Language Contact and the Written Text. Oxford: Oxford University Press, 77-102. 
Blank (1994): Blank, David L. ‘Analogy, Anomaly and Apollonius Dyscolus'. In Stephen Everson (ed.), Language. Cambridge: Cambridge University Press, 149-165.

Blank (1998): Blank, David L. Sextus Empiricus: Against the grammarians. Oxford: Clarendon Press.

Bloomer (2011): Bloomer, W. M. The School of Rome: Latin Studies and the Origins of Liberal Education. Berkeley, CA: University of California Press.

Blum (1991): Blum, Rudolf. Kallimachos: The Alexandrian Library and the Origins of Bibliography. Translated by Hans Wellisch. Madison, Wis.: University of Wisconsin Press.

Bollansée (1999): Bollansée, Jan. Hermippos of Smyrna and his Biographical Writings: A Reappraisal. Leuven: Peeters.

Boffo (1995): Boffo, Laura. 'Ancora unavolta sugli ‘archivi’ nel mondo greco: conservazione e 'publicazione' epigrafica'. Athenaeum 83, 91-130.

Bonner (1977): Bonner, S. F. Education in the Roman World: From the Elder Cato to the Younger Pliny. Berkeley: University of California.

Borchard (2012): Borchard, F. 'The LXX Myth and Rise of Textual Fixity'. JSJ 43, 1-21.

Borg (2004): Borg, Barbara E. 'Introduction'. In Barbara E. Borg (ed.), Paideia: The World of the Second Sophistic. Berlin: de Gruyter, 1-10.

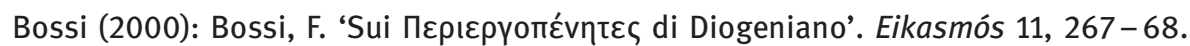

Boudon-Millot et al. (2010): Boudon-Millot, V. and J. Jouanna with A. Pietrobelli eds. Galien, Oeuvres Tome IV: Ne pas se chagriner. Paris: Les Belles Lettres.

Boussac/Invernizzi (1996): Boussac, Marie-Françoise and Antonio Invernizzi, eds. Archives et sceaux du monde hellénistique, Bulletin de correspondance hellénique supplement 29. Athens: École française d'Athènes.

Bowersock (1969): Bowersock, Glenn Warren. Greek Sophists in the Roman Empire Oxford: Clarendon Press.

Bowersock (1985): Bowersock, Glenn Warren. 'Philostratus and the Second Sophistic'. In P.E. Easterling and Bernard M.W. Knox (eds.), Cambridge History of Classical Literature, vol. 1: Greek Literature. Cambridge: Cambridge University Press, 655-62.

Bowersock (2004): Bowersock, Glenn Warren. 'Artemidorus and the Second Sophistic'. In Barbara E. Borg (ed.), Paideia. The World of the Second Sophistic. Berlin: de Gruyter, 53-64.

Bowie (1974): Bowie, Ewen. 'The Greeks and Their Past in the Second Sophistic'. In Moses I. Finley (ed.), Studies in Ancient Society. London: Routledge, 166-209.

Bowie (1978): Bowie, Ewen. 'Apollonius of Tyana: Tradition and Reality'. ANRW 2.16.2, 1652-99.

Bowie (2013): Bowie, Ewen. 'Libraries for the Caesars'. In Jason König, Katerina Oikonomopoulou and Greg Woolf (eds.), Ancient Libraries. Cambridge: Cambridge University Press, 237-60.

Boyarin (2004): Boyarin, Daniel. Border Lines: The Partition of Judaeo-Christianity. Philadelphia, PA: University of Pennsylvania Press.

Boyarin (2008): Boyarin, Daniel. 'Dialectic and divination in the Talmud'. In Simon Goldhill (ed.), The End of Dialogue in Antiquity. Cambridge: Cambridge University Press, 217-41.

Braun (2004): Braun, Willi. 'The Schooling of a Galilean Jesus Association'. In Ronald Dean Cameron and Merill P. Miller (eds.), Redescribing Christian Origins. Leiden: Brill, 43-65.

Brink (1963): Brink, Charles. Horace on Poetry: Prolegomena to the Literary Epistles. Cambridge: Cambridge University Press.

Brock (1972): Brock, S. P. 'The Phenomenon of the Septuagint'. OtSt 17, 11-36.

Brock (1977): Brock, S. P. 'Greek into Syriac and Syriac into Greek'. Journal of the Syriac Academy 3, 1-16.

Brock (1979): Brock, S. P. ‘Aspects of Translation Technique in Antiquity’. GRBS 20, 69-87.

Brock (1992): Brock, S. P. ‘To Revise or Not to Revise: Attitudes to Jewish Biblical Translation'. In G.J. Brooke and B. Lindars (eds.), Septuagint, Scrolls and Cognate Writings. SBLSCS 33. Atlanta: Scholars Press, 301-28. 
Broggiato (2000): Broggiato, M. 'Athenaeus, Crates and Attic Glosses: a problem of attribution'. In David Braund and John Wilkins (eds.), Athenaeus and his World: Reading Greek Culture in the Roman Empire. Exeter: Exeter University Press, 364-71.

Brooke (2010): Brooke, G. J. 'Genre Theory, Rewritten Bible, and Pesher'. DSD 17, 332-57.

Brooke (2017): Brooke, G. J. 'Aspects of Education in the Sectarian Scrolls from the Qumran

Caves'. In G.J. Brooke and R. Smithuis (eds.), Jewish Education from Antiquity to the Middle

Ages: Studies in Honour of Philip S. Alexander. AJEC 100. Leiden: Brill, 11-42.

Brown (1988): Brown, Peter. The Body and Society: Men, Women, and Sexual Renunciation in Early Christianity. New York, NY: Columbia University Press.

Brugnoli (1968): Brugnoli, Giorgio. Studi Suetoniani. Lecce: Milella.

Brugnoli (1984): Brugnoli, Giorgio. Foca: Vita di Virgilio: introduzione, testo, traduzione e commentato. Pisa: ETS.

Brugnoli/Stock (1997): Brugnoli, Giorgio, and Stock, Fabio. Vitae Vergilianae antiquae. Rome: Typis Officinae Polygraphicae.

Bravo (2007): Bravo, Benedetto. ‘Antiquarianism and History'. In John Marincola (ed.), $A$ companion to Greek and Roman historiography. London: Blackwell, 515-27.

De Breucker (2010): De Breucker, Geert. 'Berossos of Babylon (680)'. In lan Worthington (ed.), Brill's New Jacoby. Leiden: Brill.

De Breucker (2013): De Breucker, Geert. 'Berossos: His life and his work'. In Johannes Haubold, Giovanni B. Lanfranchi, Robert Rollinger, and John Steele (eds.), The World of Berossos. Proceedings of the 4th International Colloquium on the Ancient Near East between classical and ancient oriental traditions, Hartfield College, Durham 7th-9th July 2010. Wiesbaden: Harrassowitz, 15-28.

Burrell (2009): Burrell, B. 'Reading, Hearing and Looking at Ephesos'. In W.A. Johnson and H.N. Parker (eds.), Ancient Literacies. The Culture of Reading in Greece and Rome. Oxford: Oxford University Press, 69-95.

Butler (2008-2009): Butler, Shane. 'Cicero's capita'. Litterae Caelestes 3, 9-48.

Cabezon (1998a): Cabezon, José Ignacio, edited. Scholasticism: Cross-Cultural and Comparative Perspectives. Albany, NY: SUNY Press.

Cabezon (1998b): Cabezon, José Ignacio. 'Introduction'. In José Ignacio Cabezon (ed.), Scholasticism: Cross-Cultural and Comparative Perspectives. Albany, NY: SUNY Press, 1-17.

Canevaro/Harris (2012): Canevaro, Mirko and Edward M. Harris. 'The Documents in Andocides' On the Mysteries'. Classical Quarterly 62, 98-129.

Capasso (2003): Capasso, Mario. Il ritorno di Cornelio Gallo: il papiro di Qasr Ibrîm venticinque anni dopo. Con un contributo di Paolo Radiciotti. Napoli: Graus.

Capizzi (1955): Capizzi, Antonio. Protagora: le testimonianze e i frammenti. Florence: G. C. Sansoni.

Carandini/Carafa (2017): Carandini, A. and P. Carafa, editors. The Atlas of Ancient Rome. Princeton and Oxford: Princeton University Press.

Carawan (2007): Carawan, Edwin. 'Krateros the Macedonian (342)'. In Ian Worthington (ed.), Brill's New Jacoby. Leiden: Brill.

Cavallo (2002): Cavallo, Guglielmo. 'Un'aggiunta al 'decalogo' di Giorgio Pasquali’. In Dalla parte del libro. Storie di trasmissione dei classici. Urbino: QuattroVenti, 25-29.

Cerati/Locke (1755): Cerati, G. and J. Locke. 'Copy of a letter from a learned Gentleman of Naples, dated February 25, 1755, concerning the books and antient writings dug out of the ruins of an edifice near the site of the old city of Herculaneum; to Monsignor Cerati, of Pisa, F. R. S. Sent to Mr. Baker, FRS and by him communicated; with a translation by John Locke, Esq FRS'. Philosophical Transactions of the Royal Society 48, XXIII, 112-15.

Chandler (1881): Chandler, H. W. A practical introduction to Greek Accentuation. Oxford: Oxford University Press. 


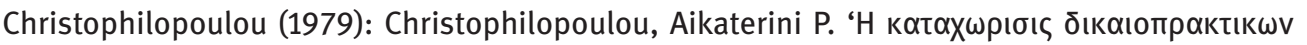

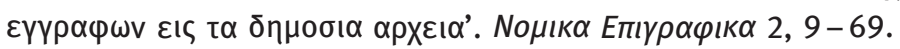

Clancier (2009): Clancier, Philippe. Les bibliothèques en Babylonie dans la deuxième moitié du $1^{\text {er }}$ millénaire av. J.-C. Münster: Ugarit-Verlag.

Claridge (2007): Claridge, A. 'Hadrian's lost temple of Trajan'. Journal of Roman Archaeology 20, $54-94$.

Claridge (2013): Claridge, A. 'Hadrian's Succession and the Monuments of Trajan'. In T. Opper (ed.), Hadrian: Art, Politics and Economy. London: British Museum, 5-18.

Clarke (1973): Clarke, Martin. 'The date of the Ciris'. CPh 68, 119-21.

Clarysse (2010): Clarysse, W. 'Bilingual Papyrological Archives'. In A. Papaconstantinou (ed.), The Multilingual Experience in Egypt, from the Ptolemies to the Abbasids. Farnham: Ashgate, 47-72.

Coarelli (2010): Coarelli, F. 'Substructio et Tabularium'. Papers of the British School at Rome 78, $107-32$.

Coates-Stevens (2006): Coates-Stevens, R. 'Un pistrinum tardo-repubblicano a Porta Maggiore'. Rendiconti della Pontificia Accademia Romana di Archeologia 78, 473-98.

Cohen (1981): Cohen, Shaye J.D. 'Patriarchs and Scholarchs'. Proceedings of the American Academy for Jewish Research 48, 57-87.

Cohen (1984): Cohen, Shaye J.D. 'The Significance of Yavneh: Pharisees, Rabbis, and the End of Jewish Sectarianism'. In The Significance of Yavneh and Other Essays in Jewish Hellenism. Tübingen: Mohr Siebeck, 44-70. Originally published in: Hebrew Union College Annual 55 (1984): $27-53$.

Cohen (1999): Cohen, Shaye J.D. 'The Rabbi in Second-Century Jewish Society'. In William Horbury, W.D. Davis, and John Sturdy (eds.), The Cambridge History of Judaism, vol. 3: The Early Roman Period. Cambridge: Cambridge University Press, 922-90.

Cohn (1895): Cohn, L. 'Arkadios 5’. In RE 2.1, 1153-56.

Cooke/Tredennick (1938): Cooke, H. P., and H. Tredennick, editors. Aristotle: Categories, On Interpretation, Prior Analytics. LCL 325. Cambridge, Mass: Harvard University Press.

Cooper (2007): Cooper, C., editor. Politics of Orality. MneSup 280. OLAC 6. Leiden: Brill.

Copeland (1991): Copeland, Rita. Rhetoric, Hermeneutics, and Translation in the Middle Ages: Academic Traditions and Vernacular Texts. Cambridge: Cambridge University Press.

Copeland (2002): Copeland, Rita. ‘Pre-Modern Intellectual Biography'. In Helen Small (ed.), The Public Intellectual. Oxford: Blackwell Publishers, 40-61.

Coqueugniot (2012): Coqueugniot, Gaëlle. 'Le chreophylakeion et l'agora d’Europos-Doura: bilan des recherches, 2004-2008'. In Pierre Leriche, Gaëlle Coqueugniot, and Ségolène de Pontbriand (eds.), Europos-Doura Varia I. Beirut: Presses de l'ifpo, 93-110.

Coqueugniot (2013): Coqueugniot, Gaëlle. Archives et bibliothèques dans le monde grec. Édifices et organisation. Oxford: BAR.

Corcoran/Salway (2012): Corcoran, Simon and Benet Salway, 'Fragmenta Londiniensia Anteiustiniana: Preliminary Observations’. Roman Legal Tradition 8, 63-83.

Cornell et al. (2013): Cornell, Tim, et al. The Fragments of the Roman Historians. 3 Vols. Oxford: Oxford University Press.

Courcelle (1968): Courcelle, Pierre. Late Latin Writers and their Greek Sources. Translated by Harry Wedeck. Cambridge: Harvard University Press.

Courtney (1993): Courtney, Edward. The Fragmentary Latin Poets. Oxford: Clarendon Press.

Cribiore (1996): Cribiore, Raffaella. Writing, Teachers, and Students in Graeco-Roman Egypt. ASP 36. Atlanta: Scholars Press.

Cribiore (2001): Cribiore, Raffaella. Gymnastics of the Mind: Greek Education in Hellenistic and Roman Egypt. Princeton: Princeton University Press. 
Cribiore (2007): Cribiore, Raffaella. The School of Libanius in Late Antique Antioch. Princeton, NJ: Princeton University Press.

De Crom (2011): De Crom, D. 'Translation and Directionality in the Hebrew-Greek Tradition'. In S. McElduff and E. Sciarrino (eds.), Complication the History of Western Translation: The Ancient Mediterranean in Perspective. Manchester: St. Jerome, 77-78.

Cugusi (2007): Cugusi, Paolo. Per un nuovo corpus dei Carmina Latina Epigraphica: materiali e discussioni. Roma: Bardi.

Cugusi (2016): Cugusi, Paolo. Versi su pietra: studi sui Carmina latina epigraphica: metodologia, problemi, tematiche, rapporti con gli auctores, aspetti filologici e linguistici, edizioni di testi: quaranta anni di ricerche. Faenza: Fratelli Lega editori.

Curnow (2006): Curnow, Trevor. Ancient Philosophy and Everyday Life. Newcastle: Cambridge Scholars Press.

D’Anna (1956): D’Anna, Giovanni. 'Sulla vita suetoniana di Terenzio'. RIL 89, 31-46.

D’Ors (1986): D’Ors, Alvaro. La ley Flavia Municipal (Texto y comentario). Rome: Pontificia Universitas Lateranensis.

Dahlmann (1963): Dahlmann, Hellfried. Studien zu Varro De poetis. Mainz: F. Steiner.

Dahlmann (1973): Dahlmann, Hellfried. 'Varroniana'. ANRW 1.3, 2-25.

Davila (2005): Davila, J. R. '(How) Can We Tell if a Greek Apocryphon or Pseudepigraphon has been Translated from Hebrew or Aramaic?'. JSP 15, 3-61.

Decorte (2015): Decorte, Robrecht. 'Publishing Laws: An Investigation of Layout and Epigraphic Conventions in Roman Statutes'. Zeitschrift für Papyrologie und Epigraphik 195, 243-54.

Del Corso (2009): Del Corso, L. 'L'Insegnamento alla luce delle testimonianze iconografiche'. In H. Huggonard-Roche (ed.), L'enseignement supérieur dans les mondes antiques et médiévaux. Textes et traditions 16. Paris: Editions VRIN, 307-31.

Dickey (2007): Dickey, Eleanor. Ancient Greek Scholarship: A Guide to Finding, Reading, and Understanding Scholia, Commentaries, Lexica, and Grammatical Treatises, from Their Beginnings to the Byzantine Period. Oxford: Oxford University Press.

Dickey (2010): Dickey, Eleanor. 'The creation of Latin teaching materials in antiquity: a re-interpretation of P.Sorb. inv. 2069'. Zeitschrift für Papyrologie und Epigraphik 175, $188-208$.

Dickey (2012-2015): Dickey, Eleanor. The Colloquia of the Hermeneumata Pseudodositheana. 2 vols. CCTC. Cambridge: Cambridge University Press.

Dickey (2014): Dickey, Eleanor. 'A Catalogue of Works Attributed to the Grammarian Herodian', Classical Philology 109, 325-45.

Dickey (2016): Dickey, Eleanor. Learning Latin the ancient way: Latin textbooks from the ancient world. Cambridge: Cambridge University Press.

Diels/Kranz (1952): Diels, Hermann, and Walther Kranz. Die Fragmente der Vorsokratiker (6th edn). Berlin: Weidmann.

Dillery (1999): Dillery, John. 'The first Egyptian narrative history: Manetho and Greek Historiography'. Zeitschrift für Papyrologie und Epigraphik 127, 93-116.

Dillery (2013): Dillery, John. 'Manetho'. In Tim Whitmarsh and Stuart Thomson (eds.), The Romance between Greece and the East. Cambridge: Cambridge University Press, 38-58.

Dindorf (1823): Dindorf, C. W. Grammatici Graeci, I. Leipzig: Libraria Kuehniana.

Dines (2004): Dines, J. M. The Septuagint. London: T\&T Clark.

Dix/Houston (2006): Dix, Keith and George Houston. 'Public Libraries in the City of Rome: From the Augustan Age to the Time of Diocletian'. MEFRA 118. 671-717.

Dixon (1997): Dixon, R. M.W. The Rise and Fall of Languages. Cambridge: Cambridge University Press.

Dorandi (1999): Dorandi, Tiziano. Antigone de Caryste. Paris: Les Belles Lettres. 
Dorandi (2007): Dorandi, Tiziano. Nell'officina dei classici: come lavoravano gli autori antichi. Rome: Carocci.

Dingel (1973): Dingel, Joachim. 'Bruchstück einer römischen Komödie auf einem Hamburger Papyrus (Afranius?)'. Zeitschrift für Papyrologie und Epigraphik 10, 29 - 44.

Dover (1968): Dover, Kenneth J. Aristophanes: Clouds. Oxford: Clarendon Press.

Dreyer (1975): Dreyer, O. 'Luseis'. KP, 832-33.

Dudley (1967): Dudley, D. R. Urbs Roma: a source book of classical texts on the city and its monuments. London: Phaidon.

Dyck (1993): Dyck, A. R. 'Aelius Herodian: Recent Studies and Prospects for Future Research'. In ANRW II 34.1, 772-94.

École nationale (1991): École nationale des Chartes, Dictionnaire des archives. De l'archivage aux systèmes d'information. Paris: AFNOR.

Eckstein (2010): Eckstein, Arthur M. 'Polybius, 'the treaty of Philinus' and Roman accusations against Carthage'. The Classical Quarterly 60, 406-26.

Edmondson (2014): Edmondson, Jonathan. 'Inscribing Roman texts: Officinae, layout, and carving techniques'. In Christer Bruun and Jonathan Edmondson (eds.), The Oxford Handbook of Latin Epigraphy. Oxford: Oxford University Press, 111-30.

Edwards (2012): Edwards, M. J. 'Religion in the Age of Marcus Aurelius'. In M. Van Ackeren (ed.), A companion to Marcus Aurelius. Chichester: Wiley-Blackwell, 200-16.

Egenolff (1881): Egenolff, P. 'In Herodianum technicum critica III'. RhM 36, 490-505.

Egenolff (1887): Egenolff, P. Die orthoepischen Stücke der byzantinischen Litteratur. Leipzig: Teubner.

Egenolff (1900): Egenolff, P. “'Zu Lentz” Herodian I’. Philologus 59, 238-55.

Egenolff (1902): Egenolff, P. “'Zu Lentz” Herodian II”, Philologus 61, 77-132, 540-76.

Egenolff (1903): Egenolff, P. “'Zu Lentz" Herodian III'. Philologus 62, 39-63.

El-Abbadi (2004): El-Abbadi, M. 'The Alexandria library in history'. In Anthony Hirst and Michael Silk (eds.), Alexandria, Real and Imagined. London: Routledge, 167-84.

Elm (2012): Elm, Susanna. Sons of Hellenism, Fathers of the Church: Emperor Julian, Gregory of Nazianzus, and the Vision of Rome. Berkeley: University of California Press.

Erbse (1969-1988): Erbse, Hartmut. Scholia graeca in Homeri lliadem. Berlin: De Gruyter.

Erskine (1995): Erskine, A. 'Culture and power in Ptolemaic Egypt: The Museum and Library of Alexandria'. Greece \& Rome 42, 38-48.

Eshleman (2012): Eshleman, Kendra. The Social World of Intellectuals in the Roman Empire: Sophists, Philosophers, and Christians. Cambridge: Cambridge University Press.

Esposito (2009): Esposito, E. 'Fragments of Greek lexicography in the papyri'. Trends in Classics 1, $255-97$.

Esposito (2011): Esposito, E. 'Review of From Alexandria to Babylon. Near Eastern Languages and Hellenistic Erudition in the Oxyrhynchus Glossary (POxy $1802+4812)$, by Francesca Schironi'. Eikasmós 22, 524-29.

Feeney (2016): Feeney, D. Beyond Greek: The Beginnings of Latin Literature. Cambridge, MA: Harvard University Press.

Fernández Marcos (2000): Fernández Marcos, N. The Septuagint in Context: Introduction to the Greek Version of the Bible. Translated by W.G.E. Watson. Leiden: Brill.

Fernández Pomar (1966): Fernández Pomar, J. M. 'La Colección de Uceda y los manuscritos griegos de Constantino Lascaris'. Emerita 34, 211-88.

Fewster (2002): Fewster, P. 'Bilingualism in Roman Egypt'. In J.N. Adams, M. Janse, and S. Swain (eds.), Bilingualism in Ancient Society: Language Contact and the Written Text. Oxford: Oxford University Press, 220-46. 
Fioretti (2012): Fioretti, Paolo. 'Ordine del testo, ordine dei testi. Strategie distintive nell'Occidente latino tra lettura e scrittura'. In Scrivere e leggere nell'alto medioevo. Spoleto, 28 aprile - 4 maggio 2011, 525-51. Spoleto: Centro Italiano di Studi sull'Alto Medioevo.

Fioretti (2016): Fioretti, Paolo. 'Percorsi di autori latini tra libro e testo. Contesti di produzione e di ricezione in epoca antica'. Segno e testo 14, 1-38.

Fischel (1977): Fischel, Henry A. Essays in Greco-Roman and Related Talmudic Literature. New York, NY: Ktav.

Fowden (1986): Fowden, Garth. The Egyptian Hermes: A Historical Approach to the Late Pagan Mind. Cambridge: Cambridge University Press.

Fraenkel (1950): Fraenkel, Eduard. Aeschylus Agamemnon. Oxford: Clarendon Press.

Fraenkel (1957): Fraenkel, Eduard. Horace. Oxford: Clarendon Press.

Frampton (2019): Frampton, S. Empire of Letters. Oxford: Oxford University Press.

Fraser (1972): Fraser, P. M. Ptolemaic Alexandria. 3 vols. Oxford: Clarendon Press.

Fraser (2009): Fraser, P. M. Greek Ethnic Terminology. Oxford: Oxford University Press.

Fraser et al. (1987-): Fraser, P. M., E. Matthews, et al. (eds.), A lexicon of Greek personal names.

Oxford: Oxford University Press.

Freudenthal (1875): Freudenthal, J. Alexander Polyhistor und die von ihm erhaltenen Reste jüdischer und samaritanischer Geschichtswerke, Hellenistische Studien I-II. Breslau: Skutsch.

Fressura (2017): Fressura, Marco. Vergilius Latinograecus. Corpus dei manoscritti bilingui dell'Eneide. Parte prima (1-8). Pisa-Rome: Fabrizio Serra editore.

Fressura/Mantovani (2018): Fressura, Marco and Dario Mantovani, ‘P.Vindob. L 59 + 92. Frammenti delle Institutiones di Elio Marciano'. Athenaeum 106, 619-690.

Funaioli (1907): Funaioli, Gino. Grammaticae Romanae fragmenta. Leipzig: Teubner.

Furstenberg (2012): Furstenberg, Yair. 'The Agon With Moses and Homer: Rabbinic Midrash and the Second Sophistic'. In Maren R. Niehoff (ed.), Homer and the Bible in the Eyes of Ancient Interpreters. Leiden: Brill, 299-328.

Galland (1882): Galland, C. De Arcadii qui fertur libro de accentibus. Strasbourg: Carolus J. Truebner.

Gallazzi (2012): Gallazzi, Claudio. 'Umm-el-Breigât (Tebtynis): campagna di scavo dell'anno 2012'. Istituto Lombardo - Accademia di Scienze e Lettere - Rendiconti di Lettere 146, 87-110.

Gamillscheg et al. (1981-): Gamillscheg, E., D. Harlfinger, and D. Hunger, Repertorium der Griechischen Kopisten. Vienna: Austrian Academy of Sciences Press.

Gartner (2002): Gartner, H. A. 'Zetema'. DNP 12, 778-79.

Gartner (2010): Gayraud, M. 'L'apprentissage du grec et du latin dans l'Empire romain d'après un manuscrit de la Bibliothèque Universitaire de Montpellier'. Bulletin de l'Académie des Sciences et Lettres de Montpellier 41, 35-44.

Geiger (1985): Geiger, Joseph. Nepos and Political Biography. Wiesbaden: Steiner.

Geiger (1994): Geiger, Joseph. 'Notes on the Second Sophistic in Palestine'. Illinois Classical Studies 19, 221-30.

Georgoudi (1988): Georgoudi, Stella. 'Manières d'archivage et archives de cités'. In Marcel Detienne (ed.), Les savoirs de l'écriture. En Grèce ancienne. Lille: Presses universitaires de Lille, 221- 47.

Gigante (1995): Gigante, M. Philodemus in Italy. The Books from Herculaneum. Translated by Dirk Obbink. Ann Arbor: University of Michigan Press.

Gignac (1981): Gignac, Francis T. A grammar of the Greek papyri of the Roman and Byzantine periods II. Milan: Istituto editoriale cisalpino La goliardica.

Goldhill (2001): Goldhill, Simon, edited. Being Greek Under Rome: Cultural Identity, the Second Sophistic and the Development of Empire. Cambridge: Cambridge University Press.

Goldhill (2008): Goldhill, Simon. 'Introduction: Why don't Christians do dialogue?'. In Simon Goldhill (ed.), The End of Dialogue in Antiquity. Cambridge: Cambridge University Press, 1-11. 
Goldschmidt (2015): Goldschmidt, Nora. 'Terence: A Guide to Selected Sources'. In Living Poets. Durham.

Gomoll (1935): Gomoll, Heinz. 'Suetons bibliotheksgeschichtliche Nachrichten'. Zentralblatt für Bibliothekswesen 52, 381-88.

González (1986): González, Julián. 'The Lex Irnitana: A New Copy of the Flavian Municipal Law'. Journal of Roman Studies 76, 147-243.

Goodblatt (1975): Goodblatt, David. Rabbinic Instruction in Sasanian Babylonia. Leiden: Brill.

Goodman (2016): Goodman, P. 'Clusters of artisans in the Roman city'. In A. Wilson and M. Flohr (eds.), Urban Craftsmen and Traders in the Roman World. Oxford: Oxford University Press, 301-33.

Goodwin (1894): Goodwin, William W. A Greek Grammar. Boston: Ginn \& Company.

Goodyear (1965): Goodyear, Francis. Incerti Auctoris Aetna. Cambridge: Cambridge University Press.

Goodyear (1984): Goodyear, Francis. 'The 'Aetna': Thoughts, Antecedents, and Style'. ANRW 2.32.1, $344-64$.

Greer (1926): Greer, Russel. 'Non-Suetonian Passages in the Life of Vergil Formerly Ascribed to Donatus'. TPAPhS 57, 107-15.

Grenfell/Hunt (1900): Grenfell, Bernard and Arthur S. Hunt, editors. Fayum Towns and Their Papyri. London: Egypt Exploration Society.

Griffin (1984): Griffin, Jasper. 'Augustus and the Poets. Caesar qui cogere posset'. In Fergus Millar and Erich Segal (eds.), Caesar Augustus: Seven Aspects. Oxford: Clarendon Press, 189-218.

Gruen (1990): Gruen, Erich S. Studies in Greek Culture and Roman Policy. Berkeley: University of California Press.

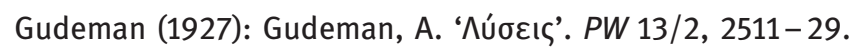

Gunderson (2009): Gunderson, E. Nox Philologiae. Aulus Gellius and the Fantasy of the Roman Library. Madison: University of Wisconsin Press.

Haake (2013): Haake, Matthias. 'Psephismata in the Biographies of Philosophers'. In Peter Liddel and Polly Low (eds.), Inscriptions and Their Uses in Greek and Latin Literature. Oxford: Oxford University Press, 79-124.

Hachlili (1989): Hachlili, Rachel. 'The State of Ancient Synagogue Studies'. In Rachel Hachlili (ed.), Ancient Synagogues in Israel. Third-Seventh Century C.E. Oxford: British Archaeological Review, 1-5.

Hahm (1992): Hahm, David. 'Diogenes Laertius VII: On the Stoics'. ANRW 2.36.2, 4076-182.

Halivni (2013): Halivni, David Weiss. The Formation of the Babylonian Talmud. Introduced, Translated, and Annotated by Jeffrey L. Rubenstein. Oxford: Oxford University Press.

Halton (1999): Halton, Thomas. Saint Jerome: On Illustrious Men. The Fathers of the Church 100. Washington D.C.: Catholic University Press of America.

Hansen (2016): Hansen, Mogens H. 'Is Teisamenos' Decree (Andoc. 1.83-84) a Genuine Document?'. Greek, Roman, and Byzantine Studies 56, 34-48.

Harding (2001): Harding, Phillip. Androtion and the Atthis. London: Clarendon.

Harding (2008): Harding, Phillip. The Story of Athens: The Fragments of the Local Chronicles of Attika. London: Routledge.

Harries (2010): Harries, Jill. 'Courts and the Judicial System'. In Catherine Hezser (ed.), The Oxford Handbook of Jewish Daily Life in Roman Palestine. Oxford: Oxford University Press, 85-101.

Hartnett (2017): Hartnett, J. The Roman Street: Urban Life and Society in Pompeii, Herculaneum, and Rome. Cambridge: Cambridge University Press.

Hartog (2017): Hartog, P. B. Pesher and Hypomenma: A Comparison of Two Commentary Traditions from the Hellenistic-Roman Period. STDJ 121. Leiden: Brill. 
Hatzilambrou (2007): Hatzilambrou, R. 'P. Oxy. XVIII 2192 revisited'. Appendix to Dirk Obbink. 'Readers and intellectuals' in Oxyrhynchus: a City and its Texts. Edited by Alan Bowman, pages 282-86. London: Egypt Exploration Society.

Hatzimichali (2013a): Hatzimichali, Myrto. ‘Encyclopedism in the Alexandrian Library’. In Jason König and Greg Woolf (eds.), Enclyclopaedism from Antiquity to the Renaissance. Cambridge: Cambridge University Press, 64-83.

Hatzimichali (2013b): Hatzimichali, Myrto. 'Ashes to Ashes? The library of Alexandria after 48 BC'. In Jason König, Katerina Oikonomopoulou and Greg Woolf (eds.), Ancient Libraries.

Cambridge: Cambridge University Press, 167-82.

Hatzimichali (2016): Hatzimichali, Myrto. 'Andronicus of Rhodes and the construction of the Aristotelian Corpus'. In Andrea Falcon (ed.), Brill's Companion to the Reception of Aristotle in Antiquity. Leiden: Brill, 81-100.

Hauptman (2005): Hauptman, Judith. Rereading the Mishnah: A New Approach to Ancient Jewish Texts. Tübingen: Mohr Siebeck.

Hayes (2017): Hayes, Christine. 'Law in Classical Rabbinic Judaism'. In Christine Hayes (ed.), The Cambridge Companion to Judaism and Law. Cambridge: Cambridge University Press, 76-127.

Heine (2010): Heine, Ronald E. Origen: Scholarship in the Service of the Church. Oxford: Oxford University Press.

Heitsch (1964): Heitsch, Ernst. Die griechischen Dichterfragmente der römischen Kaiserzeit II. Göttingen: Vandenhoeck \& Ruprecht.

Helm (1929): Helm, Rudolf. Hieronymus' Zusätze in Eusebius' Chronik und ihr Wert für die Literaturgeschichte. Philologus Supplementband 21.2. Leipzig: Dieterich'sche Verlagsbuchhandlung.

Hengel (1974): Hengel, M. Judaism and Hellenism: Studies in their Encounter in Palestine during the Early Hellenistic Period. Translated by J. Bowden. Minneapolis: Fortress Press.

Hermans (2002): Hermans, T. 'Paradoxes and Aporias in Translation and Translation Studies'. In Alessandra Riccardi (ed.), Translation Studies: Perspectives on an Emerging Discipline.

Cambridge, Cambridge University Press, 10-23.

Hezser (1997): Hezser, Catherine. The Social Structure of the Rabbinic Movement in Roman Palestine. Tübingen: Mohr Siebeck.

Hezser (2001): Hezser, Catherine. Jewish Literacy in Roman Palestine. TSA/ 81. Tübingen: Mohr Siebeck.

Hezser (2002): Hezser, Catherine. 'The Mishnah and Ancient Book Production'. In Jacob Neusner and Alan J. Avery-Peck (eds.), The Mishnah in Contemporary Perspective, vol. 1. Leiden: Brill, $167-92$.

Hezser (2016): Hezser, Catherine. 'The Torah Versus Homer: Jewish and Greco-Roman Education in Late Roman Palestine'. In Matthew Ryan Hauge and Andrew W. Pitts (eds.), Ancient Education and Early Christianity. LNTS 533. London: Bloomsbury, 5-24.

Hezser (2017a): Hezser, Catherine. Rabbinic Body Language: Non-Verbal Communication in Palestinian Rabbinic Literature of Late Antiquity. Leiden: Brill.

Hezser (2017b): Hezser, Catherine. 'Bookish Circles? The Use of Written Texts in Rabbinic Oral Culture'. Temas Medievales 25, 63-81.

Hezser (2018): Hezser, Catherine. 'The Creation of the Talmud and the Apophthegmata Patrum as Monuments to the Rabbinic and Monastic Movements in Early Byzantine Times'. Jewish Studies Quarterly 25, 368-93.

Hilgard (1901): Hilgard, A. Scholia in Dionysii Thracis Artem grammaticam (Grammatici Graeci I.III). Leipzig: Teubner.

Hirshman (2009): Hirshman, Marc. The Stabilization of Rabbinic Culture, 100 C.E. - 350 C.E. Texts On Education and Their Late Antique Context. Oxford: Oxford University Press. 
Holford-Strevens (2003): Holford-Strevens, Leofrank. Aulus Gellius: An Antonine Scholar and his Achievement. Oxford: Oxford University Press.

Holford-Strevens/Vardi (2004): Holford-Strevens, L. and A. Vardi, editors. The Worlds of Aulus Gellius. Oxford: Oxford University Press.

Holleran (2012): Holleran, C. Shopping in Ancient Rome: The Retail Trade in the Late Republic and the Principate. Oxford: Oxford University Press.

Holwerda (1991): Holwerda, D. Scholia in Vespas, Pacem, Aves et Lysistratam (Scholia in Aristophanem II.3: Scholia vetera et recentiora in Aristophanis Aves). Groningen: Egbert Forsten.

Honigman (2003): Honigman, Sylvie. The Septuagint and Homeric Scholarship in Alexandria: A Study in the Narrative of the 'Letter of Aristeas'. London: Routledge.

Honigman (2007): Honigman, Sylvie. 'The Narrative Function of the King and the Library in the Letter of Aristeas'. In T. Rajak et al. Jewish Perspectives on Hellenistic Rulers. Berkeley: University of California Press, 128-46.

Horsfall (1989): Horsfall, Nicholas. Cornelius Nepos: A Selection, including the Lives of Cato and Atticus. Oxford: Clarendon Press.

Houston (2007): Houston, George W. 'Grenfell, Hunt, Breccia and the book collections of Oxyrhynchus'. Greek, Roman and Byzantine Studies 47, 327-59.

Houston (2014): Houston, George W. Inside Roman Libraries: Book Collections and Their Management in Antiquity. Studies in the history of Greece and Rome. Chapel Hill: University of North Carolina Press.

Hudson (1980): Hudson, R. A. Sociolinguistics. CTL. Cambridge: Cambridge University Press.

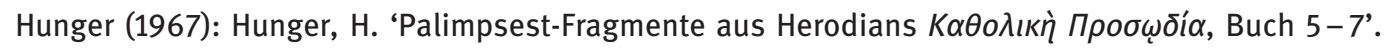
Jahrbuch der Österreichischen Byzantinischen Gesellschaft 16, 1-33.

Hunt (1927): Hunt, Arthur S., editor The Oxyrhynchus Papyri, xVII, Nos. 2065-2156. London: Egypt Exploration Society.

Isayev (2017): Isayev, E. Migration, Mobility and Place in Ancient Italy. Cambridge: Cambridge University Press.

Jacoby (1949): Jacoby, Felix. Atthis: The Local Chronicles of Ancient Athens. Oxford: Clarendon. Jaffee (2001): Jaffee, Martin S. Torah of the Mouth: Writing and Oral Tradition in Palestinian Judaism, 200 BCE - 400 CE. Oxford: Oxford University Press.

Jaffee (1991): Janowitz, N. 'The Rhetoric of Translation: Three Early Perspectives on Translating Torah'. HTR 84, 129-40.

Janse (2002): Janse, M. 'Aspects of Bilingualism in the History of Greek Language'. In J.N. Adams, M. Janse, and S. Swain (eds.), Bilingualism in Ancient Society: Language Contact and the Written Text. Oxford: Oxford University Press, 332-90.

Johnson (2010): Johnson, W. A. Readers and Reading Culture in the High Roman Empire: A Study of Elite Communities. Oxford: Oxford University Press.

Johnson/Parker (2009): Johnson, W.A. and H.N. Parker, editors. Ancient Literacies. The Culture of Reading in Greece and Rome. Oxford: Oxford University Press.

Jones (1986): Jones, Christopher P. 'Suetonius in the Probus of Giorgio Valla'. HSPh 90, 245-51. Jones (2009): Jones, Christopher P. 'Books and Libraries in a newly-discovered treatise of Galen'. Journal of Roman Archaeology 22, 390-97.

Joosten (2012): Joosten, Jan. Collected Studies on the Septuagint: From Language to Interpretation and Beyond. FAT 83. Tübingen: Mohr Siebeck.

Kaiser (2010): Kaiser, Stefan. Die Fragmente des Aristoxenos aus Tarent. Hildesheim: Olms.

Kaldellis/López Ruiz (2009): Kaldellis, Anthony and Carolina López Ruiz. 'Philon (790)’. Brill's New Jacoby. Edited by lan Worthington.

Kamesar (2009): Kamesar, A. 'Biblical Interpretation in Philo'. In A. Kamesar (ed.), The Cambridge Companion to Philo. Cambridge: Cambridge University Press, 65-94. 
Kaster (1988): Kaster, Robert. Guardians of Language: The Grammarian and Society in Late Antiquity. Berkeley: University of California Press.

Kaster (1995): Kaster, Robert. C. Suetonius Tranquillus: De Grammaticis et Rhetoribus. Oxford: Clarendon Press.

Kelly (1979): Kelly, L. The True Interpreter. New York: St. Martin's.

Kissel (1990): Kissel, Walter. Persius Flaccus, Aules, Satyren. Heidelberg: Winter Verlag.

Knauer (1993): Knauer, E. R. 'Roman wall paintings from Boscotrecase: Three studies in the relationship between writing and painting'. Metropolitan Museum Journal 28, 13-46.

König (2008): König, Jason. 'Sympotic dialogue in the first to fifth centuries C.E.'. In Simon Goldhill (ed.), The End of Dialogue in Antiquity. Cambridge: Cambridge University Press, 85-114.

König/Woolf (2013a): König, Jason and Gregg Woolf. 'Introduction’. In Jason König and Gregg Woolf (eds.), Encyclopaedism from Antiquity to the Renaissance. Cambridge: Cambridge University Press, 1-20.

König/Woolf (2013b): König, Jason and Gregg Woolf. 'Encyclopaedism in the Roman Empire'. In Jason König and Gregg Woolf (eds.), Encyclopaedism from Antiquity to the Renaissance. Cambridge: Cambridge University Press, 23-63.

van der Kooij (1998): van der Kooij, A. 'Perspectives of the Septuagint: Who are the Translators?'. In F. García Martínez and E. Noort (eds.), Perspectives in the Study of the Old Testament and Early Judaism. Leiden: Brill, 214-29.

Körtge (1901): Körtge, Gustav. In Suetonii de viris illustribus inquisitionum capita tria. Dissertationes philologicae Halenses, 14. Halle: Academia Fridericiana.

Kraemer (1996): Kraemer, David. Reading the Rabbis: The Talmud as Literature. Oxford: Oxford University Press.

Kramer (2001): Kramer, J. Glossaria bilinguia altera. Munich: K.G. Saur.

Kroll (1977): Kroll, John H. 'An archive of the Athenian cavalry'. Hesperia 46, 83-140.

Kühn (1821-1833): Kühn, K. G., edited. Claudii Galeni Opera Omnia. Leipzig: C. Cnobloch.

Lallot (1998): Lallot, J. La grammaire de Denys le Thrace: Traduite et annotée. Second edition. Paris: CNRS Editions.

Lambert (2016): Lambert, Stephen. 'The selective inscribing of laws and decrees in late classical Athens'. Hyperboreus. Studia classica 22, 217-39.

Lamberti (1993): Lamberti, Francesca. “Tabulae Irnitanae": Municipalità e “ius Romanorum”. Naples: Jovene.

Lambrinudakis/Wörrle (1983): Lambrinudakis, Wassilios and Michael Wörrle. 'Ein hellenistisches Reformgesetz über das öffentliche Urkundenweisen von Paros'. Chiron 13, 283-368.

Lane Fox (1994): Lane Fox, Robin. 'Aeschines and the Athenian democracy'. In Robin Osborne and Simon Hornblower (eds.), Ritual, Finance, Politics: Athenian democratic accounts presented to David Lewis. Oxford: Oxford University Press, 135-56.

de Lange (2015): de Lange, N. Japheth in the Tents of Shem: Greek Bible Translations in Byzantine Judaism. Texts and Studies in Medieval and Early Modern Judaism 30. Tübingen: Mohr Siebeck.

Lapin (1999): Lapin, Hayim. 'Rabbis and Cities in Later Roman Palestine: The Literary Evidence'. Journal of Jewish Studies 50, 187-207.

Lapin (2000): Lapin, Hayim. 'Rabbis and Cities: Some Aspects of the Rabbinic Movement in its Graeco-Roman Environment'. In Peter Schäfer and Catherine Hezser (eds.), The Talmud Yerushalmi and Graeco-Roman Culture, vol. 2. Tübingen: Mohr Siebeck, 51-80.

Lapin (2012): Lapin, Hayim. Rabbis As Romans: The Rabbinic Movement in Palestine, 100-400 CE. Oxford: Oxford University Press. 
Larson (2011): Larson, J. 'Bilingual Inscriptions and Translation in the Ancient Mediterranean World'. In S. McElduff and E. Sciarrino (eds.), Complicating the History of Western

Translation: The Ancient Mediterranean in Perspective. Manchester: St. Jerome, 50-61.

Latte (1925): Latte, K. 'Glossographica’. Philologus 80, 136-75.

Latte (1953): Latte, K. ‘Prolegomena’. In Hesychii Alexandrini Lexicon vol. 1. Copenhagen: Munksgaard.

Laurence (2007): Laurence, R. Roman Pompeii: Space and Society. Second edition. New York: Routledge.

Laurence/Newsome (2011): Laurence, R. and D. J. Newsome, editors. Rome, Pompeii, Ostia: Movement and Space. Oxford: Oxford University Press.

Law/Sluiter (1995): Law, V. and I. Sluiter (eds.), Dionysius Thrax and the Techne Grammatikē. Münster: Nodus Publikationen.

Lefèvre (2014): Lefèvre, Eckard. 'P. Terentius Afer'. In Werner Suerbaum (ed.), Nouvelle histoire de la littérature latine. Vol. 1: Des origines à la mort de Sylla. Turnhout: Brepols, 243-66.

Lefkowitz (2012): Lefkowitz, Mary. The Lives of the Greek Poets. London: Bloomsbury.

Lemaire (2006): Lemaire, A. 'Lire, écrire, étudier à Qoumrân et aillerus'. In A. Lemaire and S.C. Mimouni (eds.), Qoumrân et le judaïsme du tournant de notre ère: actes de la Table ronde, Collège de France, 16 Novenbre 2004. Leuven: Peeters, 63-79.

Lentz (1867): Lentz, A. Herodiani technici reliquiae. Leipzig: Teubner.

Leo (1901): Leo, Friedrich. Die griechisch-römische Biographie. Leipzig: Teubner.

Levine (1989): Levine, Lee I. The Rabbinic Class of Roman Palestine in Late Antiquity. Jerusalem: The Jewish Theological Seminary.

Lianeri/Zajko (2008): Lianeri, A., and V. Zajko, editors. Translation and the Classics: Identity As Change in the History of Culture. Oxford: Oxford University Press.

Liddell et al. (1996): Liddell, H. G., R. Scott, H. S. Jones, R. McKenzie, P. G. W. Glare, and A. A. Thompson, A Greek-English Lexicon. Ninth edition with revised supplement. Oxford: Clarendon Press.

Lieberman (1962): Lieberman, Saul. Hellenism in Jewish Palestine. Second edition. New York, NY: Jewish Theological Seminary of America.

Lieberman (1965): Lieberman, Saul. Greek in Jewish Palestine. Second edition. New York, NY: Jewish Theological Seminary of America.

Lightstone (2002): Lightstone, J. N. Mishnah and the Social Formation of the Early Rabbinic Guild. A Socio-Rhetorical Approach. Waterloo, Ontario: Wilfrid Laurier University Press.

Lindsay (1994): Lindsay, Hugh. 'Suetonius as 'ab epistulis' to Hadrian and the Early History of the Imperial Correspondence'. Historia 43, 454-68.

Lindsay (1995): Lindsay, Hugh. 'Suetonius on the Character of Horace'. AUMLA 83, 69-82. Lobeck (1837): Lobeck, C. A. Paralipomena Grammaticae Graecae, I-II. Lepizig: Weidmann. Lopez-Ruiz (2008): Lopez-Ruiz, Carolina. 'Hieronymos the Egyptian (787)'. In Ian Worthington (ed.), Brill's New Jacoby.

Loyd (1969): Loyd, James. Books in Suetonius' De Vita Caesarum. Diss. North Carolina.

Lyne (1971): Lyne, Oliver. 'The Dating of the Ciris'. CQ 21, 233-53.

Lyne (1978): Lyne, Oliver. Ciris: A Poem Attributed to Vergil. Cambridge: Cambridge University Press.

Lyne (1995): Lyne, Oliver. Horace: Behind the Public Poetry. New Haven: Yale University Press.

Machiela (2010): Machiela, D. A. 'Once More, with Feeling: Rewritten Scripture in Ancient Judaism -A Review of Recent Developments'. JJS 61, 308-20.

Makrinos (2011): Makrinos, A. 'Paraphrases'. In M. Finkelberg (ed.), The Homer Encyclopedia. Oxford: Blackwell, 2.626-27.

Mallon (1952): Mallon, Jean. Paléographie romaine. Madrid: Instituto Antonio de Nebrija de Filologia. 
Mallon (1982): Mallon, Jean. De l'écriture. Recueil d'études publiées de 1937 à 1981. Paris: Centre nationale de la recherche scientifique.

Mantovani (2015): Mantovani, Dario. 'Tituli e capita nelle Institutiones di Gaio e nell'Epitome Gai. Contributo allo studio del paratesto negli scritti dei giuristi romani'. Seminario Complutenses de derecho romano $28,587-622$.

Mantovani (2017): Mantovani, Dario. 'ERC-Project Redhis: A new appreciation of Juristic texts and Patterns of thought in Late Antiquity. Il programma e i primi risultati'. In Sebastian Lohsse, Salvatore Marino, and Pierangelo Buongiorno (eds.), Texte wiederherstellen, Kontexte rekonstruieren. Stuttgart: Franz Steiner Verlag, 167-88.

Mantovani (2018): Mantovani, Dario. Les juristes écrivains de la Rome antique. Les oeuvres des juristes comme littèrature. Paris: Les Belles Lettres.

Marec/Pflaum (1952): Marec, Ervan, and Hans-Georg Pflaum. 'Nouvelle inscription sur la carrière de Suétone, l'historien'. CRAI 96, 76-85.

Marrou (1956): Marrou, H. I. A History of Education in Antiquity. Translated by G.R. Lamb. London: Sheed and Ward.

Martina (1984): Martina, Mario. 'Le vite antiche di Lucano e di Persio'. CCC 5, 155-89.

Martínez Manzano (1994): Martínez Manzano, T. Konstantinos Laskaris: Humanist, Philologe, Lehrer, Kopist. Hamburg: Arbeitsbereich II, Byzantinistik und Neugriechische Philologie des Instituts für Griechische und Lateinische Philologie der Universität Hamburg.

Mason (2003): Mason, Steve. Flavius Josephus, Life of Josephus: Translation and Commentary. Leiden: Brill.

Matthaios (2010): Matthaios, S. 'Lexikographen über die Schulter geschaut: Tradition und Traditionsbruch in der griechischen Lexikographie'. In Marietta Horster and Christiane Reitz (eds.), Condensed Texts-Condensing Texts. Stuttgart: Franz Steiner, 165-207.

Matthaios et al. (2011): Matthaios, S., F. Montanari, and A. Rengakos, editors. Ancient Scholarship and Grammar: Archetypes, Concepts and Contexts. TCSup 8. Berlin: de Gruyter.

Matusova (2015): Matusova, E. The Meaning of the Letter of Aristeas: In Light of Biblical Interpretation and Grammatical Tradition, and with Reference to its Historical Context. FRLANT 260. Göttingen: V\&R.

Matusova (2018): Matusova, E. 'The Origins of Translation Theory: The LXX among Jewish Greek Writers'. In M. Meiser, M. Geiger, S. Kreuzer, and M. Sigismund (eds.), Die Septuaginta Text, Wirkung, Rezeption: 6. Internationale Fachtagung veranstaltet von Septuaginta Deutsch (LXX.D), Wuppertal 20-24 Juli 2016. Tübingen: Mohr Siebeck, 557-72.

Mazhuga (2003): Mazhuga, Vladimir. 'A quelle époque vivait le grammairien Phocas?' RPh 77, 67-77.

Mazzarino (1955): Mazzarino, Antonio. Grammaticae Romanae Fragmenta aetatis Caesaris. Turin: Loescher.

Mazzarino (1973-1974): Mazzarino, Antonio. ‘Appunti sul metodo II: Intorno all'età e all'opera di Foca'. Helikon 13-14, 505-27.

McElduff (2009): McElduff, S. 'Living at the Level of the Word: Cicero's Rejection of the Interpreter as Translator'. Translation Studies 2, 133-46.

McElduff (2013): McElduff, S. Roman Theories of Translation: Surpassing the Source. RMCS 14. London: Routledge.

McGill (2010): McGill, Scott. 'Another man's miracles: recasting Aelius Donatus in Phocas's Life of Virgil'. In Scott McGill, Cristiana Sogno, and Edward Watts (eds.), From the Tetrarchs to the Theodosians: Later Roman History and Culture, 284-450 CE. Cambridge: Cambridge University Press, 153-70.

McNamee (2007): McNamee, Kathleen. Annotations in Greek and Latin Texts from Egypt. Chippenham: American Studies in Papyrology. 
Mélèze-Modrzejewski (1995): Mélèze-Modrzejewski, J. 'Law and Justice in Ptolemaic Egypt'. In Legal Documents of the Hellenistic World: Papers from a Seminar Arranged by the Institute of Classical Studies, the Institute of Jewish Studies and the Warburg Institute, University of London, February to May 1986. London: Warburg Institute, 1-19.

Mendels/Edrie (2011): Mendels, Doron and Ayre Edrei. Zweierlei Diaspora. Zur Spaltung der antiken jüdischen Welt. Göttingen: Vandenhoeck \& Ruprecht.

ní Mheallaigh (2008): ní Mheallaigh, Karen. 'Pseudo-Documentarianism and the Limits of Ancient Fiction'. AJP 129, 403-31.

Miles (2000): Miles, Richard. 'Communicating culture, identity, and power'. In Janet Huskinson (ed.), Experiencing Rome: Culture, Identity and Power in the Roman Empire. London: Routledge, 29-62.

Miller (1895): Miller, Julius. ‘Apollonios von Tyana [98]'. RE 2.1. 146-48.

Moioli (1987): Moioli, Maria Lauretta. 'La famiglia di Sarapion alias Apollonianus stratego dei nomi Arsinoites ed Hermopolites'. Acme 40, 123-36.

Montanari (2015a): Montanari, Franco. 'Ekdosis. A product of the ancient scholarship'. In Franco Montanari, Stephanos Matthaios and Antonios Rengakos (eds.), Brill's Companion to Classical Scholarship. Leiden: Brill, 641-72.

Montanari (2015b): Montanari, Franco. ‘Hellenistic Scholarship’. In Franco Montanari, Stephanos Matthaios and Antonios Rengakos (eds.) Brill's Companion to Ancient Greek Scholarship. 2 vols. Leiden: Brill, 1.60-183.

Montanari et al. (2015): Montanari, Franco, Stephanos Matthaios, and Antonios Rengakos, editors. Brill's Companion to Ancient Greek Scholarship, 2 vols. Leiden and Boston, MA: Brill.

Montanari/Pagani (2011): Montanari, Franco and Lara Pagani, editors. From Scholars to Scholia: Chapters in the History of Ancient Greek Scholarship. Berlin: de Gruyter.

Montanari/Perrone (2009): Montanari, F. and S. Perrone, editors. Fragments of the Past: Ancient Scholarship and Greek Papyri. TiC 1. Berlin: de Gruyter.

Moore (2015): Moore, S. Jewish Ethnic Identity and Relations in Hellenistic Egypt: With Walls of Iron?. SupJSJ 171. Leiden: Brill.

Morgan (1998): Morgan, Teresa. Literate Education in the Hellenistic and Roman Worlds. CCS. Cambridge: Cambridge University Press.

Morgan (2013): Morgan, Teresa. 'Encyclopaedias of Virtue? Collections of Sayings and Stories About Wise Men in Greek'. In Jason König and Gregg Woolf (eds.), Encyclopaedism from Antiquity to the Renaissance. Cambridge: Cambridge University Press, 108-28.

Mossman (1999): Mossman, J. 'Is the Pen Mightier than the Sword? The Failure of Rhetoric in Plutarch's Demosthenes'. Histos 3, 77-101.

Most (2003): Most, G. W. 'Violets in Crucibles: Translating, Traducing, Transmuting'. TAPA 133, $380-90$.

Mugridge (2016): Mugridge, A. Copying Early Christian Texts: A Study of Scribal Practice. WUNT 362. Tübingen: Mohr Siebeck.

Mulliez (1992): Mulliez, Dominique. 'Les actes d'affranchissement delphiques'. Cahiers du Centre Gustave Glotz 3, 31-44.

Munari (1944): Munari, Franco. Studi sulla Ciris. Florence: Accademia d'Italia.

Nachmanson (1918): Nachmanson, Ernst. Erotiani vocum Hippocraticarum collectio cum fragmentis. Gothenburg: Eranos.

Naiden (2008): Naiden, Fred S. 'Menander (783)'. In Ian Worthington (ed.), Brill's New Jacoby.

Naoumides (1969): Naoumides, M. 'The Fragments of Greek Lexicography in the Papyri'. In Classical Studies Presented to Ben Edwin Perry by his students and colleagues at the University of Illinois, 1924-60. Urbana: University of Illinois Press, 181-202.

Nasti (2016): Nasti, Fara. 'Papiniano perduto? Una nuova testimonianza sull'estensione della lex Falcidia alle donationes mortis causa'. Index 44, 113-22. 
Naumann (1979): Naumann, Heinrich. 'Lücken und Einfügungen in den Dichter-Viten Suetons'. WS 92, $151-65$.

Naumann (1981): Naumann, Heinrich. 'Suetonius' Life of Virgil: The Present State of the Question'. HSPh 85, $185-87$.

Neusner (2002): Neusner, Jacob. 'The Mishnah in Roman and Christian Contexts'. In Jacob Neusner and Alan J. Avery-Peck (eds.), The Mishnah in Contemporary Perspective. Leiden: Brill, $121-48$.

Neusner (2004): Neusner, Jacob. How Not to Study Judaism. Examples and Counter-Examples, vol. 1: Parables, Rabbinic Narratives, Rabbis’ Biographies, Rabbis' Disputes. Lanham, ML: University Press of America.

Nicholls (2010): Nicholls, Matthew C. 'Parchment Codices in a new text of Galen'. Greece \& Rome $57,378-86$.

Nicholls (2011a): Nicholls, Matthew C. 'Bibliotheca Latina Graecaque: on the possible division of Roman libraries by language’. Latomus 327: SIEN Neronia VIII, 11-21.

Nicholls (2011b): Nicholls, Matthew C. 'Galen and libraries in the Peri Alupias'. Journal of Roman Studies 101, $123-42$.

Nicholls (2014): Nicholls, Matthew C. ‘A library at Antium?’ In C. K. Rothschild and T. W. Thompson (eds.), Galen's De Indolentia: essays on a newly discovered letter. Studien und Texte zu Antike und Christentum 88 Tübingen: Mohr Siebeck, 65-78.

Nickau (1966): Nickau, Klaus. Ammonii qui dicitur liber de adfinium vocabulorum differentia. Leipzig: Teubner.

Nicolai (2000): Nicolai, R. 'Review of Jocelyn Penny Small "Wax Tablets of the Mind, Cognitive Studies of Memory and Literacy in Classical Antiquity”. Athenaeum 88, 343-47

Niehoff (2011): Niehoff, M. R. Jewish Exegesis and Homeric Scholarship in Alexandria. Cambridge: Cambridge University Press.

Nisbet (2007): Nisbet, Robin. 'Horace: Life and Chronology'. In Stephen Harrison (ed.), The Cambridge Companion to Horace. Cambridge: Cambridge University Press, 7-21.

O’Hara (2010): O’Hara, James. 'The Unfinished Aeneid?' In Joseph Farrell and Michael Putnam (eds.), A Companion to Vergil's Aeneid and its Tradition. Chichester: Wiley-Blackwell, $96-106$.

Orlinsky (1975): Orlinsky, H. M. 'The Septuagint as Holy Writ and the Philosophy of the Translators'. HUCA 46, 89-114.

Östenberg et al. (2015): Östenberg, I., S. Malmberg and J. Bjørnebye, editors. The Moving City Processions: Passages and Promenades in Ancient Rome. London: Bloomsbury.

Packer (1997): Packer, J. The Forum of Trajan in Rome. A Study of the Monuments, I- III. Berkeley: University of California Press.

Palombi (1990): Palombi, D. 'Gli horrea della Via Sacra: degli apunti di G. Boni ad un ipotesi su Nerone'. Dialoghi di archeologia 8, 53-72.

Papaconstantinou (2010): Papaconstantinou, A. 'Introduction'. In A. Papaconstantinou (ed.), The Multilingual Experience in Egypt, from the Ptolemies to the Abbasids. Farnham: Ashgate, $1-16$.

Paratore (1946): Paratore, Ettore. Una nuova ricostruzione del “De Poetis” di Suetonio. Rome: Casa editrice Gismondi.

Pedech (1964): Pedech, Paul. La méthode historique de Polybe. Paris: Les Belles Lettres.

Pelletier (1962): Pelletier, A. Lettre d'Aristée à Philocrate. Sources chrétiennes 89. Paris: Éditions du Cerf.

Peirano (2012): Peirano, Irene. The Rhetoric of the Roman Fake: Latin Pseudepigraphia in Context. Cambridge: Cambridge University Press.

Pfeiffer (1949): Pfeiffer, Rudolf. Callimachus, 1: Fragmenta. Oxford: Clarendon Press. 
Pfeiffer (1968): Pfeiffer, Rudolf. History of Classical Scholarship: from the beginnings to the end of the Hellenistic age. Oxford: Oxford University Press.

Piccolomini (1879): Piccolomini, E. 'Estratti inediti dei codici greci della bibliotheca Mediceo-Laurentiana, I. Scolii alle orazioni di Gregorio Nazanzeno'. Annali delle Università Toscane 17, 231-78.

Pietersma (2002): Pietersma, A. 'A New Paradigm for Addressing an Old Question: The Relevance of the Interlinear Model for the Study of the Septuagint'. In Johann Cook (ed.), Bible and Computer. The Stellenbosch AIBI-6 Conference: Proceedings of the Association Internationale Bible et Informatique "From Alpha to Byte". 17-21 July, 2000. Leiden: Brill, 337-64.

Platthy (1968): Platthy, J. Sources on the Earliest Greek Libraries with Testimonia. Amsterdam, Hakkert.

Powell (1995): Powell, J. G. F. 'Cicero's translations from the Greek'. In Cicero the Philosopher: Twelve Papers. Edited by J.G.F. Powell, pages 273-300. Oxford: Clarendon Press.

Power (2010): Power, Tristan. 'Pliny, Letters 5.10 and the Literary Career of Suetonius'. JRS 100, $140-62$.

Power (2014): Power, Tristan. 'Juvenal, Satires 3.74 and Suetonius'. CW 107, 399-403.

Power (2016): Power, Tristan. 'Poetry and Fiction in Suetonius' Illustrious Men'. In Koen De Temmeman and Kristoffel Demoen (eds.), Writing Biography in Greece and Rome: Narrative Technique and Fictionalization. Cambridge: Cambridge University Press, 217-39.

Probert (2006): Probert, Philomen. Ancient Greek Accentuation. Oxford: Oxford University Press.

Probert (2011): Probert, Philomen. 'Attic irregularities: their reinterpretation in the light of Atticism'. In Stephanos Matthaios, Franco Montanari, and Antonios Rengakos (eds.), Ancient Scholarship and Grammar. Berlin: De Gruyter, 269-90.

Purcell (1993): Purcell, N. 'Atrium Libertatis'. Papers of the British School at Rome 61, 125-55.

Quack (2005): Quack, J. F. Einführung in die altägyptische Literaturgeschichte III: Die demotische und gräko-ägyptische Literatur. Munster: LIT Verlag.

Radt (2002-2005): Radt, S. Strabons Geographica. 4 vols. Göttingen: Vandenhoeck \& Ruprecht.

Rajak (2009): Rajak, T. Translation and Survival: The Greek Bible of the Ancient Jewish Diaspora. Oxford: Oxford University Press.

Reed (2008): Reed, Annette Yoshiko. “Jewish Christianity” as Counter-History? The Apostolic Past in Eusebius' Ecclesiastical History and the Pseudo-Clementine Homilies'. In Gregg Gardner and Kevin L. Osterloh (eds.), Antiquity in Antiquity. Jewish and Christian Pasts in the Greco-Roman World. Tübingen: Mohr Siebeck, 173-216.

Reeve (1984a): Reeve, Michael. 'Terence'. In Leighton Reynolds (ed.), Texts and Transmission. Oxford: Clarendon Press, 413-20.

Reeve (1984b): Reeve, Michael. 'The Addressee of the "Laus Pisonis"'. ICS 9, 42-48.

Reeve (2011): Reeve, Michael. 'The Vita Plinii'. In Roy Gibson and Ruth Morello (eds.), Pliny the Elder: Themes and Contexts. Leiden: Brill, 207-22.

Regenbogen (1950): Regenbogen, Otto. 'Pinax'. RE 20.2, 1408-82.

Regenbogen (1860): Reifferscheid, August. C. Suetoni Tranquilli praeter Caesarum libros reliquiae. Leipzig: Teubner.

Rhodes (2004): Rhodes, Peter J. 'The laws of Athens in the Aristotelian Athenaion Politeia'. In Delfim F. Leão, Livio Rosetti and Maria do Céu Fialho (eds.), Nomos. Direito e sociedade na Antiguidade Classica. Madrid: Ediciones Clasicas, 75-87.

Rhodes (2007): Rhodes, Peter J. 'Documents and the Greek historians'. In John Marincola (ed.), $A$ Companion to Greek and Roman Historiography. London: Blackwell, 56-66.

Rhodes (2014): Rhodes, Peter J. Atthis: The ancient histories of Athens. Heidelberg: VerlagAntike.

Richardson (1992): Richardson Jr., L. A New Topographical Dictionary of Ancient Rome. Baltimore: Johns Hopkins University Press. 
Robbins (2002): Robbins, Vernon K. 'Appendix: A Comparison of Mishnah Gittin 1:1-2:2 and James 2:1-13 from the Perspective of Greco-Roman Rhetorical Elaboration'. In Jack N. Lightstone (ed.), Mishnah and the Social Formation of the Early Rabbinic Guild. A Socio-Rhetorical Approach. Waterloo, Ontario: Wilfrid Laurier University Press, 201-16.

Robert (1961): Robert, Louis. 'Les épigraphies et l'épigraphie grecque et romaine'. In C. Samarran (ed.), L’histoire et ses méthodes. Paris: Pléiade, 453-97.

Robertson (1976): Robertson, Noel. 'False documents at Athens: fifth-century history and fourth-century publicists'. Historical Reflections 3, 3-24.

Rochette (1996): Rochette, B. 'Sur le bilinguisme dans l'Égypte gréco-romaine'. ChrEg 71, 153-68.

Rochette (1997): Rochette, B. Le latin dans le monde grec: recherches sur la diffusion de la langue et des lettres latines dans les provinces hellénophones de l'Empire romain. Brussels: Latomus.

Rostagni (1935): Rostagni, Augusto. 'La Vita suetoniana di Tibullo e la constituzione del Corpus Tibullianum'. RFIC 13, 20-51.

Rostagni (1944): Rostagni, Augusto. Suetonio: De poetis e biografi minori. Turin: Chiantore.

Roth (1858): Roth, Karl. C. Suetoni Tranquilli quae supersunt omnia. Leipzig: Teubner.

Rouse/Rouse (2000): Rouse, R.H. and M.A. Rouse. Manuscripts and their Makers: Commercial book producers in medieval Paris 1200-1500. Turnhout: Brepols.

Roussou (2018): Roussou, S. Pseudo-Arcadius' Epitome of Herodian's De Prosodia Catholica. Oxford: Oxford University Press.

Rubenstein (2003): Rubenstein, Jeffrey L. The Culture of the Babylonian Talmud. Baltimore, MD: The Johns Hopkins University Press.

Rudd (1989): Rudd, Niall. Horace, Epistles Book II and Epistle to the Pisones ('Ars Poetica'). Cambridge: Cambridge University Press.

Rutherford (2016): Rutherford, I. 'Introduction: Interaction and Translation between Greek Literature and Egypt'. In I. Rutherford (ed.), Greco-Egyptian Interactions: Literature, Translation, and Culture 500 BCE-300 CE. Oxford: Oxford University Press, 1-39.

Salanitro (1938): Salanitro, Nino. Tibullo. Naples: Casa editrice Luigi Loffredo.

Salati (2018): Salati, Ornella. 'Questioni di diritto militare in un inedito papiro londinese: P.Lond. inv. 2585r e P.Fay. 10 + P.Berol. inv. 11533’. ZPE 205, 228-46.

Saldarini (1994): Saldarini, Anthony J. Matthew’s Christian-Jewish Community. Chicago, IL: University of Chicago Press.

Salmenkivi (2002): Salmenkivi, Erja. Cartonnage Papyri in Context: New Ptolemaic Documents from Abu Sir al-Malaq. Helsinki: Societas Scientaiarum Fennica.

Salvadore (1999): Salvadore, Marcello. M. Terenti Varronis Fragmenta omnia quae extant. Vol 1. Hildesheim: Olms.

Samely (2002): Samely, Alexander. Rabbinic Interpretation of Scripture in the Mishnah. Oxford: Oxford University Press.

Scaffai (1994): Scaffai, M. 'Traduttori latini di Omero'. In R. Degl'Innocenti, S. Orlando and M.P. Pieri (eds.), La traduzione tra antico e moderno: teoria e prassi; atti del convenvo, Firenze 6-7 dicembre 1991. Florence: Polistampa, 59-72.

Scafuro (2013): Scafuro, Adele. 'Keeping Record, Making Public. The Epigraphy of Government'. In Hans Beck (ed.), A Companion to Ancient Greek Government. London: Wiley, 400-16.

Schäfer (1991): Schäfer, Peter. 'Der vorrabbinische Pharisäismus'. In Martin Hengel and Ulrich Heckel (eds.), Paulus und das antike Judentum. Tübingen: Mohr Siebeck, 125-75.

Schäfer (1927-1935): Schanz, Martin and Carl Hosius. Geschichte der römischen Literatur bis zum Gesetzgebungswerk des Kaisers Justinian, 2 Vols. Munich: Beck.

Schartau (1994): Schartau, B. Codices Graeci Haunienses. ein deskriptiver Katalog des griechischen Handschriftenbestandes der Königlichen Bibliothek Kopenhagen. Copenhagen: Museum Tusculanum Press. 
Schironi (2009): Schironi, F. From Alexandria to Babylon: Near Eastern Languages and Hellenistic Erudition in the Oxyrhynchus Glossary (P.Oxy. $1802+4812)$. Sozomena 4. Berlin: de Gruyter. Schmidt (1922): Schmidt, Friedrich. Die Pinakes des Kallimachos. Berlin: Ebering.

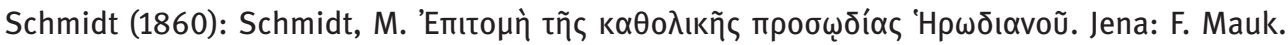

Schmidt (1991): Schmidt, Peter. 'Suetons Pratum seit Wessner (1917)'. ANRW 2.33.5, 3794-825.

Schmidt (1994): Schmidt, Peter. 'Horaz'. RAC 16, 491-524.

Schmidt (2000): Schmidt, Peter. 'C. Suetonius Tranquillus'. In Klaus Sallmann (ed.), Nouvelle histoire de la littérature latine. Vol. 4: L’âge de transition 117-284. Paris: Brepols, 14-58.

Schofer (2005): Schofer, Jonathan Wyn. The Making of a Sage: A Study in Rabbinic Ethics. Madison, WI: University of Wisconsin Press.

Schofield (2008): Schofield, Malcolm. 'Ciceronian dialogue'. In Simon Goldhill (ed.), The End of Dialogue in Antiquity. Cambridge: Cambridge University Press, 63-84.

Schon (2004): Schon, Stefan. Satyros aus Kallatis: Sammlung der Fragmente mit Kommentar. Basel: Schwabe.

Schwartz (1995): Schwartz, Seth. 'Language, Power and Identity in Ancient Palestine'. Past and Present 148, 3- 47.

Schwartz (2008): Schwartz, Seth. 'No dialogue at the symposium? Conviviality in Ben Sira and the Palestinian Talmud'. In Simon Goldhill (ed.), The End of Dialogue in Antiquity. Cambridge: Cambridge University Press, 193-216.

Sedley (2012): Sedley, D. 'Cicero and the Timaeus'. In M. Schofield (ed.), Aristotle, Plato, and Pythagoreanism in the First Century BC: New Directions for Philosophy. Cambridge: Cambridge University Press, 187-205.

Shackleton Bailey (1993): Shackleton Bailey, D. R. translator. Martial. Epigrams, Volume II: Books 6-10. Loeb Classical Library 95, and Epigrams, Volume I: Spectacles, Books 1-5. Loeb Classical Library 94 Cambridge, MA: Harvard University Press.

Shear (1935): Shear, T. L. 'The campaign of 1933'. Hesperia 4, 311-39.

Shear (1995): Shear Jr., T. Leslie. 'Bouleuterion, Metroon and the Archives at Athens'. In Mogens H. Hansen and Kurt Raaflaub (eds.), Studies in the ancient Greek Polis. Papers from the Copenhagen Polis Centre 6. Stuttgart: Historia Einzelschriften, 157-90.

Shemeh (2009): Shemeh, Aharon. Halakhah in the Making: The Development of Jewish Law from Qumran to the Rabbis. Berkeley: University of California Press.

Shutt (1985): Shutt, R. J. H. 'Letter of Aristeas'. In James Charlesworth (ed.), Old Testament Pseudepigrapha. 2 vols. New Haven: Yale University Press, 2.7-34.

Sickinger (1999): Sickinger, James. Public records and archives in classical Athens. Chapel Hill: University of North Carolina Press.

Sider (2005): Sider, J. D. The Library of the Villa dei Papyri at Herculaneum. Los Angeles: J. Paul Getty Museum.

Siebenborn (1976): Siebenborn, Elmar. Die Lehre von der Sprachrichtigkeit und ihren Kriterien. Amsterdam: Grüner.

Siméoni (1998): Siméoni, D. 'The Pivotal Status of the Translator’s Habitus'. Target 10, 1-39. Singer (1997): Singer, P. N. Galen, Selected Works. Oxford: Oxford World's Classics.

Sluiter (2000a): Sluiter, Ineke. 'The Rhetoric of Scepticism: Sextus against the Language Specialists'. In Juha Sihvola (ed.), Ancient Scepticism and the Sceptical Tradition (Acta Philosophica Fennica 66). Helsinki: Philosophical Society of Finland, 93-123.

Sluiter (2000b): Sluiter, Ineke. 'The Dialectics of Genre: Some Aspects of Secondary Literature and Genre in Antiquity'. In Mary Depew and Dirk Obbink (eds.), Matrices of Genre: Authors, Canons, and Society. Cambridge, Mass.: Harvard University Press, 183-203.

Sluiter (2011): Sluiter, Ineke. 'A champion of analogy: Herodian's On lexical singularity'. In Stephanos Matthaios, Franco Montanari, and Antonios Rengakos (eds.), Ancient Scholarship and Grammar. Berlin: De Gruyter, 293-310. 
Smith (1978): Smith, O. L. 'Urbano da Belluno and Copenhagen GKS 1965, 4’'. Scriptorium 32, 57-59.

Smyth (1956): Smyth, Herbert W. Greek Grammar. Revised by G. M. Messing. Cambridge, Mass.: Harvard University Press.

Snyder (2000): Snyder, H. Gregory. Teachers and Texts in the Ancient World: Philosophers, Jews and Christians. London: Routledge.

Sommerstein (1991): Sommerstein, Alan H. The comedies of Aristophanes III: Clouds. Warminster: Aris \& Phillips.

Spanoudakis (2002): Spanoudakis, K. Philitas of Cos. Leiden: Brill.

van der Spek (2008): van der Spek, R. J. 'Berossus as a Babylonian chronicler and Greek historian'. In R. J. van der Spek et al. (eds.), Studies in Ancient Near Eastern World View and Society presented to Marten Stol on the occasion of his 65th birthday, 10 November 2005, and his retirement from the Vrije Universiteit Amsterdam. Bethesda MD: CDL Press, 277-318.

Speyer (1971): Speyer, Wolfgang. Die litterarische Fälschung im heidnischen und christlichen Altertum: Eine Versuch ihrer Deutung. Munich: Beck.

Speyer (2002): Spooner, J., editor. Nine Homeric papyri from Oxyrhynchos. Florence: Istituto Papirologico “G. Vitelli”.

Stasse (2009): Stasse, Baudouin. 'Le traité d’Apamée chez Polybe. Questions de forme'. Cahiers du Centre Gustave Glotz 20, 249-63.

Steinby (1999): Steinby, E. M., editor. Lexicon Topographicum Urbis Romae. Rome: Edizioni Quasar.

Stem (2005): Stem, Rex. 'Nepos' Atticus as a Biography of Friendship'. SLLRH 12, 115-29.

Stenger (2017): Stenger, Jan. 'What Does it Mean to Call the Monasteries of Gaza a 'School'? A Reassessment of Dorotheus' Intellectual Identity'. Vigiliae Christianae 71, 59-84.

Stok (2010): Stok, Fabio. 'The Life of Vergil before Donatus'. In Joseph Farrell and Michael Putnam (ed.), A Companion to Vergil's Aeneid and its Tradition. Chichester: Wiley-Blackwell, 107-20.

Stronk (2011): Stronk, J. 'Herodotus and Ctesias: Translators of the Oriental Past'. In S. McElduff and E. Sciarrino (eds.) Complication the History of Western Translation: The Ancient Mediterranean in Perspective. Manchester: St. Jerome, 101-16.

Stroud (1978): Stroud, Ronald S. 'State documents in archaic Athens'. In Athens comes of age. From Solon to Salamis. Princeton: Archaeological Institute of America, 20-42.

Stroud (1979): Stroud, Ronald S. The Axones and Kyrbeis of Drakon and Solon. Berkeley: University of California Press.

Strzelecki (1936): Strzelecki, Władystaw. 'De Phocae vita Vergiliana'. In Munera Philologica Ludovico Cwiklinski oblata. Posnan: Societas Philologiae Polonorum, 235-52.

Swain (1996): Swain, Simon. Hellenism and Empire: Language, Classicism, and Power in the Greek World, AD 50-250. Oxford: Clarendon Press.

Swain (2006): Swain, Simon. 'Beyond the Limits of Greek Biography: Galen from Alexandria to the Arabs'. In Brian McGing and Judith Mossman (eds.), The Limits of Ancient Biography. Swansea: The Classical Press of Wales, 395-434.

Swartz (1998): Swartz, Michael D. 'Scholasticism as a Comparative Category and the Study of Judaism'. In José Ignacio Cabezon (ed.), Scholasticism: Cross-Cultural and Comparative Perspectives. Albany, NY: SUNY Press, 91-114.

Swete (2000): Swete, H. B. An Introduction to the Old Testament in Greek. Cambridge: Cambridge University Press.

Syme (1980): Syme, Ronald. 'Guard Prefects of Trajan and Hadrian'. JRS 70, 64-80.

Syme (1986): Syme, Ronald. The Augustan Aristocracy. Oxford: Clarendon Press.

Tacoma (2016): Tacoma, L. E. Moving Romans: Migration to Rome in the Principate. Oxford: Oxford University Press. 
Tarrant (1984): Tarrant, Richard. 'Horace'. In Leighton Reynolds (ed.), Texts and Transmission. Oxford: Clarendon Press, $182-86$.

Tatum (2011): Tatum, Jeffrey. 'The Late Republic: Autobiographies and Memoirs in the Age of the Civil Wars'. In Gabriele Marasco (ed.), Political Autobiographies and Memoirs in Antiquity. Leiden: Brill, 161-88.

Tcherikover/Fuks (1957): Tcherikover, V. A., and A. Fuks, editors. Corpus Papyrorum Judaicarum. 3 vols. Cambridge, MA: Harvard University Press.

Terzaghi (1931): Terzaghi, Nicola. Prolegomeni a Terenzio. Turin: Edizioni de L’Erma.

Thomas (1979): Thomas, Richard. 'Review of Oliver Lyne, Ciris: A Poem Attribute to Vergil (Cambridge: Cambridge University Press, 1978)'. Phoenix 33, 181-82.

Thompson (2008): Thompson, D. 'The Ptolemaic Library Project'. Acta Antiqua 48, 67-72.

Thompson (1966): Thompson, H. A. 'Activity in the Athenian Agora: 1960-1965’. Hesperia 35, $37-54$.

Thompson/Wycherley (1957): Thompson, H. A., and R.E. Wycherley, The Athenian Agora III. Princeton: The American School of Classical Studies at Athens.

Too (2001): Too. Y. L., editor. Education in Greek and Roman Antiquity. Leiden: Brill.

Tosi (2015): Tosi, R. 'Typology of Lexicographical Works'. In F. Montanari, S. Matthaios, and A. Rengakos (eds.), Brill's Companion to Ancient Greek Scholarship. 2 vols. Leiden: Brill, $1.622-36$.

Townend (1961): Townend, Gavin. 'The Hippo Inscription and the Career of Suetonius'. Historia 10, 99-109.

Tränkle (2000): Tränkle, Hermann. 'Q. Septimius Florens Tertullianus'. In Klaus Sallmann (ed.), Nouvelle histoire de la littérature latine. Vol. 4: L'âge de transition 117-284. Paris: Brepols, 494-571.

Trapp (1994:) Trapp, E., W. Hörandner, et al. (eds.) Lexikon zur Byzantinischen Gräzität. Vienna.

Tropper (2003): Tropper, Amram. 'Tractate Avot and Early Christian Succession Lists'. In Adam H. Becker and Annette Yoshiko Reed (eds.), The Ways That Never Parted: Jews and Christians in Late Antiquity and the Early Middle Ages. Tübingen: Mohr Siebeck, 159-88.

Tucci (2005): Tucci, P. L. 'Where High Moneta leads her steps sublime. The "Tabularium" and the Temple of Juno Moneta'. Journal of Roman Archaeology 18, 6-33.

Tucci (2008): Tucci, P. L. 'Galen's storeroom, Rome’s libraries, and the fire of A.D. 192'. Journal of Roman Archaeology 21, $133-49$.

Tucci (2013): Tucci, P. L. 'Flavian libraries in Rome'. In J. König, K. Oikonomopoulou, and G. Woolf (eds.), Ancient Libraries. Cambridge: Cambridge University Press, 277-91.

Tuplin (2000): Tuplin, Christopher. 'Nepos and the Origins of Political Biography'. SLLRH 10, $124-61$.

Turner (1952): Turner, E.G. 'Roman Oxyrhynchus'. Journal of Egyptian Archaeology 38, 78-93.

Ucciardello (2012): Ucciardello, G. Hypomnemata papiracei e lessicografia, tra Alessandria e Bisanzio. Messina: Università degli studi.

Van Groningen (1963): Van Groningen, B.A. 'EK $\Delta O \Sigma I \Sigma$ '. Mnemosyne 16, 1-17.

Vandorpe (2009): Vandorpe, Katelijn. 'Archives and dossiers'. In Roger S. Bagnall (ed.), The Oxford Handbook of Papyrology. Oxford: Oxford University Press, 216-55.

Veenhof (1986): Veenhof, Klaas R. ‘Cuneiform archives. An introduction’. In Klaas R. Veenhof (ed.), Cuneiform Archives and Libraries. Papers read at the 30th Rencontre Assyriologique Internationale. Leiden, 4-8 July 1983. Leiden: Nederlands historisch-archaeologisch Instituut te Istanbul, 1-36.

Veltri (2006): Veltri, G. Libraries, Translations, and "Canonic" Texts: The Septuagint, Aquila, and Ben Sira in the Jewish and Christian Traditions. JSJSup 109. Leiden: Brill.

Vendryes (1945): Vendryes, J. Traité d' accentuation grecque. Paris: C. Klincksieck. 
Volk (2005): Volk, Katharina. 'Aetna oder Wie man ein Lehrgedicht schreibt'. In Niklas Holzberg (ed.), Die Appendix Vergiliana: Pseudepigraphen im literarischen Context. Tübingen: Narr, 68-89.

Walbank (1990): Walbank, Frank W. Polybius. Berkeley: University of California Press.

Wallace-Hadrill (1983): Wallace-Hadrill, Andrew. Suetonius: The Scholar and his Caesars. London: Duckworth.

Walz (1833): Walz, Christian (ed.) Rhetores Graeci vol. V, Stuttgart and Tubingen: J. G. Cotta.

Wardle (2002): Wardle, David. 'Suetonius as ab epistulis: An African Connection'. Historia 51, 462-80.

Watson (1998): Watson, Alan. The Digest of Justinian. Volume 2. Philadelphia: University of Pennsylvania Press.

Watts (2006): Watts, Edward J. City and School in Late Antique Athens and Alexandria. Berkeley, CA: University of California Press.

Watts (2012): Watts, Edward J. 'Education: Speaking, Thinking, and Socializing'. In The Oxford Handbook of Late Antiquity. Edited by Scott Fitzgerald Johnson, pages 467-86. Oxford: Oxford University Press.

Wehrli (1974): Wehrli, Fritz. Die Schule des Aristoteles. Supplementband I: Hermippos der Kallimacheer. Basel: Schwabe.

Welkenhuysen (1968): Welkenhuysen, Andreas. 'Document juridique ou exercise d'écriture? Le P.Mich. VII 431 reconsidéré’. In Willy Peremans (ed.), Antidorum W. Peremans sexagenario ab alumnis oblatum. Louvain: Louvain University Press, 309-16.

West (1969): West, S. 'The Greek Version of the Letter of Tefnut'. JEA 55, 161-83.

West (1990): West, Martin L. 'Colloquialism and Naive Style in Aeschylus'. In E. M. Craik (ed.), Owls to Athens: Essays on Classical Subjects Presented to Sir Kenneth Dover. Oxford: Oxford University Press, 3-12. Reprinted in M. L. West (ed.), Hellenica II. Oxford: Oxford University Press, 2013, 203-14.

White (1993): White, Peter. Promised Verse: Poets in the Society of Augustan Rome. Cambridge, Mass.: Harvard University Press.

White (2009): White, Peter. 'Bookshops in the Literary Culture of Rome'. In W.A. Johnson and H.N. Parker (eds.), Ancient Literacies. The Culture of Reading in Greece and Rome. Oxford: Oxford University Press, $268-87$.

Whitmarsh (2005): Whitmarsh, Tim. The Second Sophistic. Oxford: Oxford University Press.

Wibier (2014): Wibier, Matthijs. 'The topography of the law book: common structures and modes of reading'. In Laura Jansen (ed.), The Roman Paratext: Frames, Texts, Readers. Cambridge: Cambridge University Press, 56-72.

von Wilamowitz-Moellendorff (1921): von Wilamowitz-Moellendorff, U. Geschichte der Philologie. Leipzig: Teubner.

Wilson (2007): Wilson, N. G. 'Scholiasts and Commentators'. Greek, Roman, and Byzantine Studies 47, 39-70.

Winsbury (2009): Winsbury, R. The Roman Book: Books, Publishing and Performance in Classical Rome. London: Bristol Classical Press.

Wise (2015): Wise, M. O. Language and Literary in Roman Judaea: A Study of the Bar Kokhba Documents. AYBRL. New Haven: Yale University Press.

Wouters (1979): Wouters, A. The Grammatical Papyri from Graeco-Roman Egypt: Contributions to the Study of the 'Ars Grammatica' in Antiquity. Brussels: Paleis der Academiën.

Wouters/Swiggers (2014): Wouters, A. and P. Swiggers, 'Word Classes (mérē toû lógou), Ancient Theories of'. In Georgios Giannakis (ed.), Encyclopedia of Ancient Greek Language and Linguistics. Leiden: Brill.

Wright (2003): Wright III, B. G. 'Access to the Source: Cicero, Ben Sira, The Septuagint and Their Audiences'. JSJ 34, 1-27. 
Wright (2006): Wright III, B. G. 'The Letter of Aristeas and the Reception History of the Septuagint'. BIOSCS 39, 47-67.

Wright (2008): Wright III, B. G. 'Transcribing, Translating, and Interpreting in the Letter of Aristeas: On the Nature of the Septuagint'. In A. Voitila and J. Jokiranta (eds.), Scripture in Translation: Essays on Septuagint, Hebrew Bible and Dead Sea Scrolls in Honour of Rija Sollamo. JSJSup 126. Leiden: Brill, 147-61.

Wright (2015): Wright III, B. G. The Letter of Aristeas: 'Aristeas to Philocreates' or 'On the Translation of the Law of the Jews'. CEJL. Berlin: de Gruyter.

Wycherley (1957): Wycherley, R.E. The Athenian Agora, Vol. 3, Literary and Epigraphical Testimonia. Princeton: the American School of Classical Studies.

Xenakis (1969): Xenakis, Jason. Epictetus Philosopher - Therapist. The Hague: Martinus Nijhoff.

Xenis (2015a): Xenis, G. Iohannes Alexandrinus Praecepta Tonica. Berlin: De Gruyter.

Xenis (2015b): Xenis, G. 'Michael Syncellus: A neglected source for Aelius Herodian's $\Pi \varepsilon p \grave{~}$

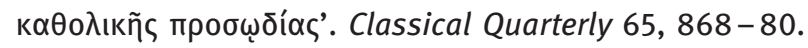

Yunis (2003): Yunis, Harvey, ed. Written texts and the rise of literate culture in ancient Greece. Cambridge: Cambridge University Press.

Zahn (2012): Zahn, M. M. 'Genre and Rewritten Scripture: A Reassessment'. JBL 131, 271-88.

Zanker (1995): Zanker, Paul. The Mask of Socrates: The Image of the Intellectual in Antiquity. Berkeley: University of California Press.

Ziegler (2016): Ziegler, Joseph. Sapientia lesu Filii Sirach. Septuaginta; Vetus Testamentum Graecum Auctoritate Academiae Litterarum Gottingensis editum vol. XII, 2. Third edition. Göttingen: V\&R.

Zuntz (1959): Zuntz, G. 'Aristeas Studies II: Aristeas on the Translation of the Torah'. JSS 4, $109-26$. 